\title{
Global imbalances, the US dollar, and how the crisis at the core of global finance spread to self-insuring` emerging market economies
}

\author{
Jörg Bibow*
}

This paper investigates the spread of what started as a crisis at the core of the global financial system to emerging economies. While emerging economies had exhibited some resilience through the early stages of the financial turmoil that began in the summer of 2007, they have been hit hard since mid-2008. Their deteriorating fortunes are only partly attributable to the collapse in world trade and sharp drop in commodity prices. Things were made worse by emerging markets' exposure to the turmoil in global finance itself. As innocent bystanders, even countries that had taken out self-insurances proved vulnerable to the global sudden stop' in capital flows. We critique loanable funds theoretical interpretations of global imbalances and offer an alternative explanation that emphasizes the special status of the US dollar. Instead of taking out even more self-insurance, developing countries should pursue capital account management to enlarge their policy space and reduce external vulnerabilities.

JEL classifications: $E_{I 2}, E_{43}, E_{44}, F_{02}, F_{I 0}, F_{32}, F_{33}, F_{42}$

Keywords: financial crisis, capital flows, self-insurance, capital controls, Bretton Woods II Hypothesis, Global Saving Glut Hypothesis

* Levy Economics Institute and Skidmore College.

Correspondence Address:

Jörg Bibow, Economics Department, Harder Hall 204C, Skidmore College, 8I5 North Broadway, Saratoga Springs, NY I2866, e-mail: jbibow@skidmore.edu.

Received I5 January 20I0, accepted I9 June 2010

C INTERVENTION 7 (2), 20IO, 325-359 


\section{Introduction}

Until the mid-2008, the 'decoupling hypothesis - that emerging markets would be sufficiently strong to escape infection from troubles at the core of the world economy - had currency among commentators and market players alike. In retrospect, emerging economies did indeed exhibit some resilience through the early stages of the financial turmoil that began in the summer of 2007, but they got hit hard in the second half of 2008. This paper investigates the spreading of what started as a crisis at the core of the global financial system to emerging economies. It argues that emerging economies' infection is only partly attributable to the collapse in world trade and sharp drop in commodity prices. Matters were made worse by exposures to the turmoil in global finance. The analysis focuses on countries that had taken out self-insurances and were able to avoid drawing on IMF help. Even in their case, however, self-insurance proved to be of limited effectiveness against the global ssudden stop of 2008.

The analysis begins with a broad overview of the channels of transmission and crisis contagion in Section 2. In Section 3, a sample of I4 leading emerging economies then provides the basis for a comparative country analysis of the global crisis. Addressing some critical systemic issues regarding self-insurance and the implied need for someone to underwrite such self-insurance, Section 4 critiques the loanable funds theoretical interpretations of global imbalances and offers an alternative explanation that emphasizes the special status of the US dollar. The concluding Section 5 discusses the policy options available to developing countries in light of the crisis experience, arguing in favor of capital account management to enlarge policy space and reduce external vulnerabilities.

\section{Decoupling, infection, recoupling: Channels of transmission and contagion}

Arguably, the global equity market sell-off in late February and March 2007 provided the first warning of things to come. Rising delinquencies and defaults on subprime mortgages had started to cause some concerns earlier in December 2006. Announcements by HSBC of a higher-than-expected charge on its US subprime loan portfolio for 2006 and a plunge on the Shanghai stock exchange then combined to send a shockwave through global equity markets. S Subprime king` New Century Financial Corporation became the first prominent lender to go under in what was soon labeled the subprime mortgage crisis (Richardson/ Zuckerman 2007, Zuckerman 2007). Yet as the Federal Reserve refrained from following through with a widely expected rate hike on March 2I, dropping its tightening bias, markets recovered and reached new highs in the spring.

Not for long though. Market stress reemerged in June 2007 as several European banks and investment vehicles became implicated in subprime-mortgage-related losses and experienced funding problems as a result (Germany's IKB and France's BNP Paribas, for instance). August 9, 2007 marks the definite beginning of the severe turmoil at the core of 
the global financial system, forcing central banks to provide emergency liquidity as interest rates shot up and money markets seized up.

At this early stage, a prominent theme among commentators was that the turmoil might be contained as emerging market economies sdecouple from slowing growth in advanced economies (see Bergsten 2008, for instance). The IMF's World Economic Outlook of October 2007 also nourished the idea that emerging economies were strong enough to decouple from the storm that was building up force at the center of global finance, observing that

"strong domestic demand growth in emerging market economies should continue to be a key driver of global growth, with more robust public balance sheets and policy frameworks providing scope for most countries to weather some weakening in external demand. Indeed, somewhat slower capital inflows from the torrid pace of the first half of 2007 may serve to ease concerns about excessive currency appreciation or too rapid credit growth« (IMF 2007).

While risks to domestic demand were seen as downward in advanced economies, they were judged as sbroadly balanced in emerging economies.

The IMF became slightly more cautious in its April 2008 World Economic Outlook referring to >divergence rather than full `decoupling developing and emerging economies had a remarkable resilience. This new found resilience was attributable, in the Fund's view, to sound policy choices since

"most emerging and developing economies have maintained disciplined macroeconomic policies in recent years, bringing down fiscal deficits and reducing inflation. Public balance sheets have been strengthened, and external vulnerabilities have been substantially reduced as international reserves have risen to historic highs and reliance on external borrowing has been largely contained« (IMF 2008).

These supposedly sound policy choices and the issue of strong capital inflows as apparently posing policy challenges to receiving countries at that time will be discussed further below in Section 4. Before that we first present some summary statistics that document the stark disappointment of these initial decoupling hopes.

Figure I shows how much worse the world economy, both advanced and developing countries, fared in 2009 compared to both the Asian crises of $1997-98$ and the global slowdown of 200I. In the developing world, GDP growth held up fairly well until mid2008 , but then plunged sharply until the spring of 2009 as international trade fell off the cliff; in fact, it declined more sharply than during the I930s (Eichengreen/O'Rourke 2009). The high degree of synchronicity in the global trade slump is revealed in Figure 2, which shows year-on-year growth rates in monthly merchandise trade (value). Figure 2 pinpoints the final quarter of 2008 and the first quarter of 2009 as the climax of decline, with recovery starting in spring 2009 .

In general, the more open and export-dependent, the more strongly economies were impacted by the slump in trade volumes. Among advanced economies, Germany and Japan fared far worse than the United States and France, for instance. Among developing 
Figure I: The great recession in global GDP and trade

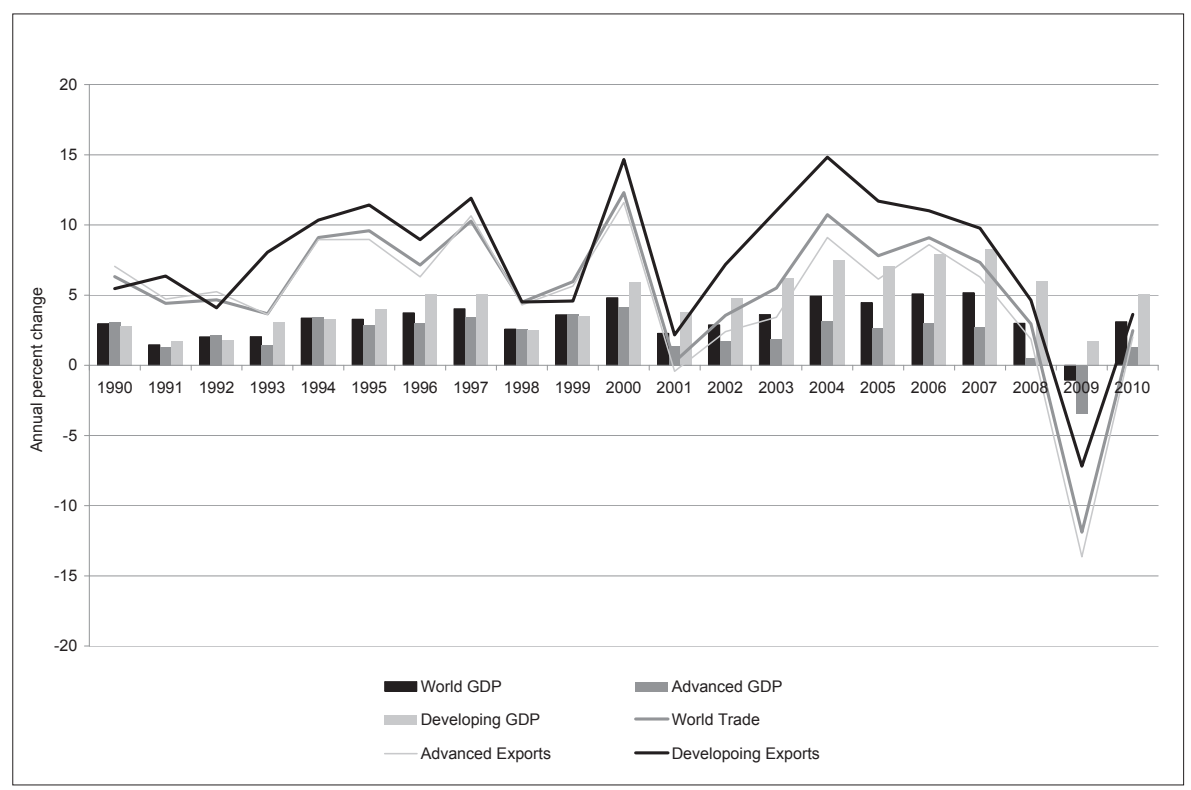

Source: IMF (WEO database Oct 2009)

Figure 2: Merchandise exports in synchronized free fall

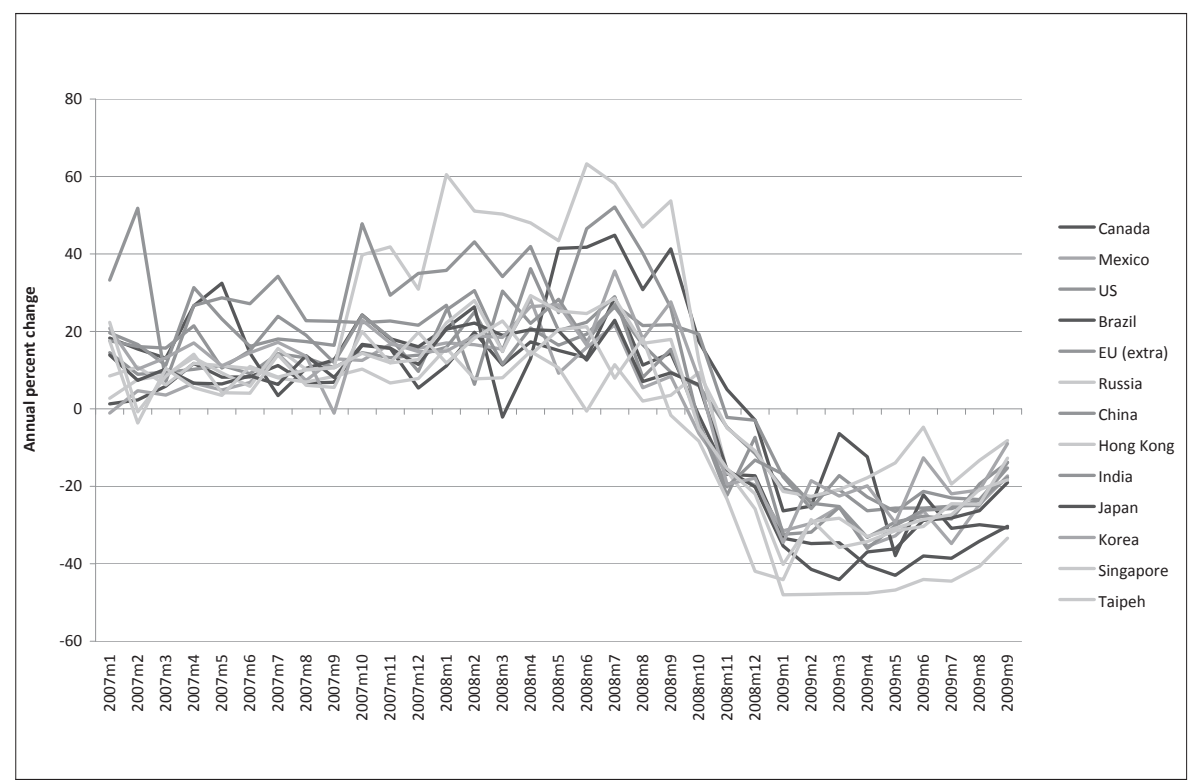

Source: WTO 
Figure 3: Commodity price boom and bust

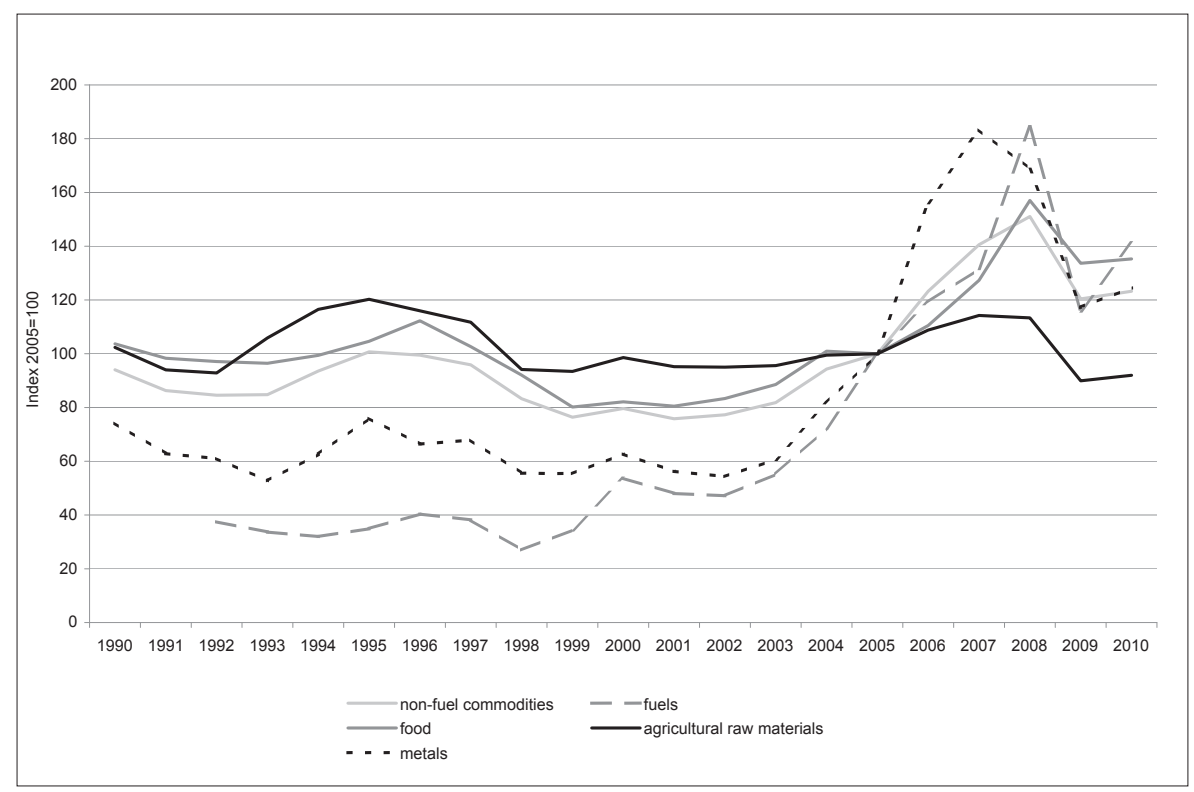

Source: IMF (WEO database Oct 2009)

Figure 4: Temporary decoupling in equity markets

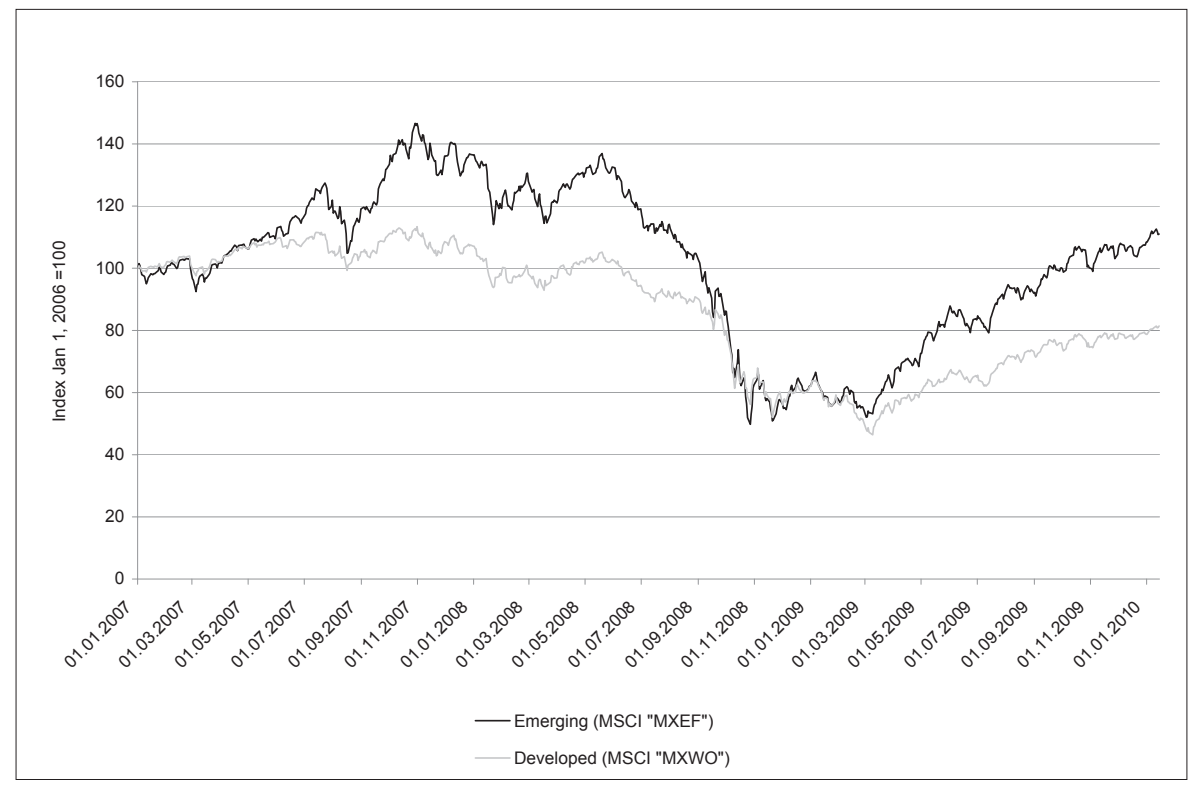

Source: MSCI Barra 
countries, China fared worse than India, as the latter is less open and its trade structure biased toward commercial services rather than manufacturing and merchandise trade.

Commodity price developments provided another channel of transmission, albeit with diverse impacts on developing countries. Following years of booming commodity prices, the Great Recession featured a very sharp price decline. For instance, the oil price had reached record highs of over US\$ I4O a barrel by mid-2008, only to crash subsequently and end the year below US \$ 50 per barrel. The very sizeable terms-of-trade effects involved here impacted countries differently depending on whether the country was a net commodity importer or exporter. For instance, net oil-exporting regions in Northern Africa and the Middle East that had benefited from record fuel prices until mid-2008 saw their fortunes swiftly reverse (and previously bloated current account surpluses deflated accordingly) as the crisis reached its climax following the Lehman debacle. By contrast, for oil and/or commodity importing nations such as the United States, EU, and China the commodity price bust meant significant relief. Note that the annual index numbers in Figure 3 show that the commodity price boom only ended about a year after the financial crisis had started. ${ }^{\mathrm{I}}$ Commodity prices peaked in the summer of 2008, plunging sharply in the second half.

Commodity prices thereby revealed similar patterns to those found in trends in global finance more generally around that time. For instance, emerging market equity indices soared in the fall of 2007, despite the turmoil that had emerged at the center over the summer, and then mostly held up well until the spring of 2008, while mature market indices moved sideways over 2007 as a whole and then sagged quite significantly in 2008, even before the Lehman bankruptcy (see Figure 4).

Furthermore, emerging market currencies generally continued to appreciate during the initial stages of the crisis, as shown in Figure 5.

These broad trends only ended in the fall of 2008 - rather abruptly - as the Lehman bankruptcy triggered a general crisis in confidence. With the ensuing general /flight for quality` focusing on US Treasuries as `safe haven`, the US dollar appreciated sharply. ${ }^{2}$ Commodity, equity, and currency trends during this period are indicative of the ssudden stop (or reversal) in international capital flows that occurred in the fall of 2008 . The sudden stop followed an initial surge in private flows towards emerging markets. As the decoupling themer was running high among players, the final surge even topped the series of boom years since 2002. Featuring the so-called global capital flows paradox of soaring foreign exchange (FX)

I Suffice to mention here that remittances have provided another channel of transmission through which developing countries were infected from the center. Remittances had grown strongly since $200 \mathrm{I}$ to reach US $\$ 305$ billion in 2008. World Bank (2009) estimates suggest an aggregate decline of 5-8 percent in 2009, but diversity exists regarding the timing and magnitude of the impact on individual countries. For instance, Mexican migrants felt the US housing bust earlier than Indian migrants came to feel the oil-price bust hitting the Middle East. Remittances from the United States to Mexico for the first eleven months of 2009 registered a whooping decline of $\mathrm{I} 6$ percent on the same period of the previous year (Buchanan 2009).

2 Carry-trade unwinding was part of the play, too, with the Japanese yen surging even more than the dollar. See McCauley/McGuire (2009). 
Figure 5: Currency movements before and since fall 2008

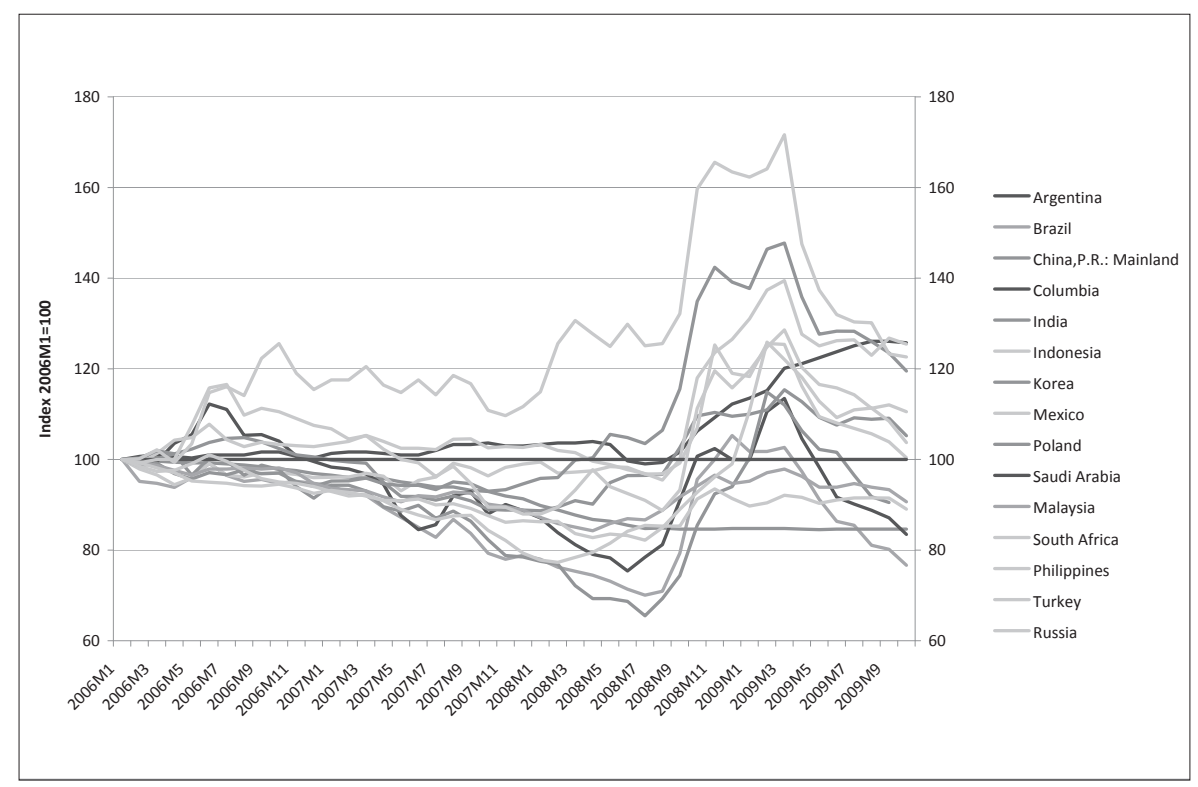

Source: IMF (IFS)

reserve holdings in the developing world since the late I990s (see Bibow [2008]) - sourced both from current account surpluses and net private capital inflows - Figure 6 shows an abrupt shrinkage or drying up of both sources in $2008 .^{3}$

To summarize this overview of broad trends and developments before and during the crisis, the infection of the developing world with the disease spreading from the core of global finance in advanced economies happened through both trade and finance channels. While the collapse in trade was highly synchronous across the globe, private capital flows at first followed the decoupling theme and flooded emerging markets, to then ebb abruptly - hitting with a vengeance delayed by about one year, which completed the recoupling of emerging market countries with advanced economies (see BIS 2009, Griffith-Jones/Ocampo 2009, IIF 2009a and 2009b, and World Bank 2009).

A key feature of semerging markets is their greater financial openness compared to developing countries at large. ${ }^{4}$ While individual emerging market experiences with global finance on the run will be investigated in the next section, trade finance may be singled out in advance here as the most general and direct link between trade and finance in the global

3 Global foreign reserves peaked around US $\$ 7$ trillion in mid-2008, but fell nearly 5 percent in the second half of the year, then to rise again and reach US\$7.5 trillion in the third quarter of 2009 . Roughly two-thirds of global reserves are held in US dollars. See IMF COFER database.

4 Bernanke (2009) provides broad evidence that financial openness was associated with greater declines in output in the crisis. 
Figure 6: Paradoxical capital flows - and suddens stop

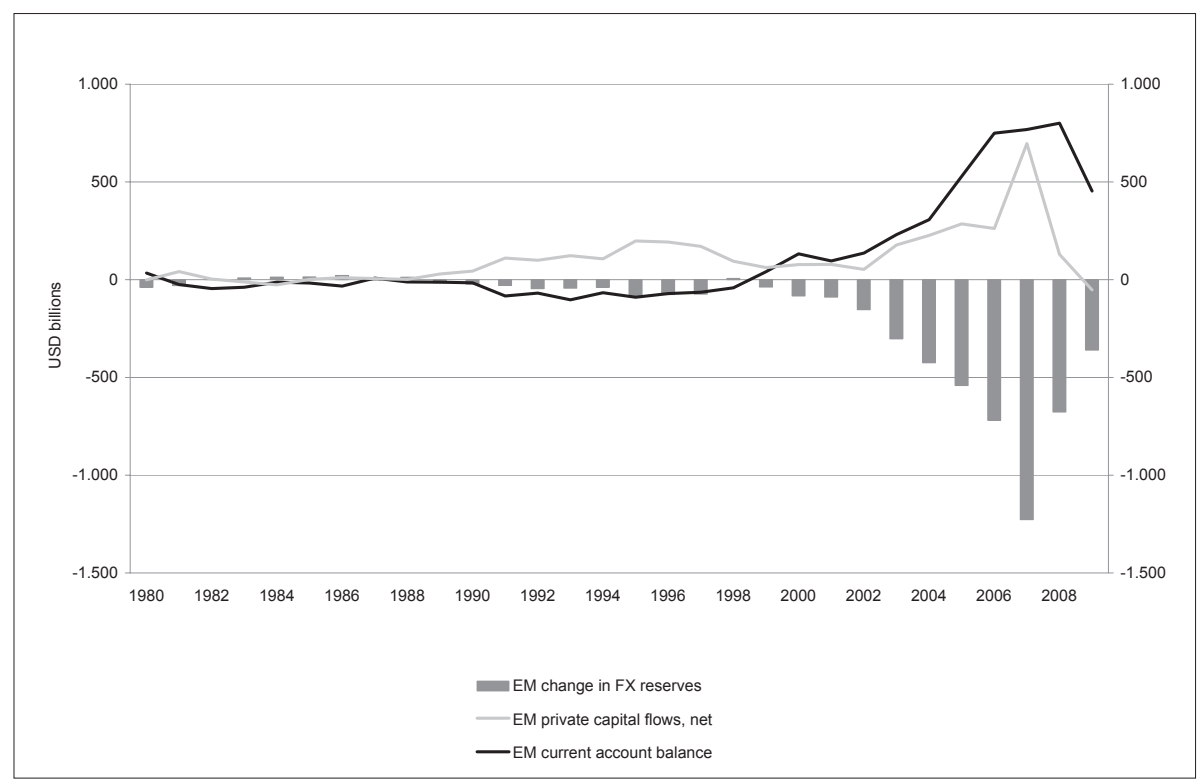

Notes: EM series include the WEO groups "Other emerging market and developing countries« and "Newly industrialized Asian economies«. For the "change in FX reserves« series a minus sign indicates increase.

\section{Source: IMF (WEO database Oct 2009)}

crisis that affected the developing world at large. Market conditions for trade finance began to tighten in the first half of 2008 and worsened rather drastically after midyear. While difficult to quantify precisely, the World Bank estimates that the widespread trade credit squeeze may have been responsible for IO - Is percent of the decline in global trade (Auboin 2009, see also Malouche 2009).5 As in the case of domestic production for domestic sale, production for international sale requires finance to be effectuated. While the short-term, self-liquidating nature of trade finance would seem to render it very secure, challenges posed by incomplete information and trust may loom especially large in transactions across bor-

5 The global volume of trade finance is estimated at US $\$$ IO - I2 trillion (or 80 percent of trade flows valued at US $\$$ I5 trillion in 2008), about 80 percent of which is supplied by private banks. Trade finance includes loans, insurance policies, and guarantees directly tied to international transactions. Loans may be bank loans or direct credit extended by exporters (i.e., , trade credit by nonfinancial firms). Apart from the provision of working capital, the private financial sector offers preshipment export finance and export credit insurance, issues or endorses letters of credit, etc. National export credit agencies and other public sector institutions - as well as regional development banks and the World Bank/IFC - provide credit and guarantee products, too. See WTO (2009), Auboin (2004 and 2009), and Wynne/Kersting (2009). 
ders and jurisdictions. A wide range of credit insurance products and guarantees provided by private and public institutions usually helps to facilitate international trade and its financing. Yet as global interbank markets seized up and large banks failed to refinance trade credit exposures on secondary markets, and as general deleveraging beset global finance, the general credit meltdown also squeezed access to trade finance. ${ }^{6}$ The point is that in a crisis of confidence, fears of failure to secure finance tomorrow may be sufficient to induce an urge to liquidate inventories and curtail production today. ${ }^{7}$ Facing buyers perceived to be more severely credit constrained will also encourage exporters to reduce their own risk exposures. In conjunction with the increased role of global supply chains in just-in-time production for international trade (see Escaith 2009, for instance), disruptions in trade financing operations further reinforced imploding trade multipliers. In short, in the sphere of trade finance, too, global finance also proved non-neutral and rather contagious in spreading the crisis globally.

Further investigating the disruptive forces of global finance as they showed up in multifarious forms around the globe, the next section pays particular attention to emerging markets that had taken out sufficient self-insurances to be able to escape the need to call on the IMF for their rescue. In principle, capital inflows tend to lead to currency appreciation in the recipient country, worsening its competitiveness and current account position. There is a structural impact on the economy that is adverse to development and catching up as traded-goods industries are hit that typically experience above-average productivity growth. Whole industries may get wiped out as the exchange rate overshoots and eventually crashes - in a crisis that causes more damages, which may get further magnified as the IMF is called to the 'rescues. In order to avoid this, countries facing capital inflows may intervene in currency markets to stem the appreciation and maintain a competitive exchange rate. The aggregate results of this widely used strategy of self-insurance were seen in Figure 6 above: soaring reserve holdings sourced from both current account surpluses and private capital inflows.

Taking out self-insurance was pursued as a precautionary strategy to avoid the influence of the IMF and to increase policy space. It is thus something of an irony that the IMF should attest that countries managed to reduce their external vulnerabilities by increasing international reserves and containing of external borrowing (see above quotation). Recall that back in the I990s the IMF championed capital account liberalization. Crises experiences and IMF rescues - with the stings of >conditionality attached, convinced countries to avoid a repeat of such experiences - and self-insure instead.

6 Among many other things, these experiences severely question the traditional dichotomy between international trade and international finance in the economics curriculum.

7 This is a most drastic illustration of Keynes's ,finance motiver at work; see Bibow (2009a). 


\section{Effectiveness of >self-insurance??}

The decoupling hypothesis was based on the idea that disciplined macroeconomic policies had established strong fundamentals across much of the emerging market universe, including strong fiscal and external positions and low inflation. More to the point, policy choices in these countries judged as sound featured competitive exchange rates, current account surplus positions, and huge FX reserve holdings. Robust fundamentals established by such self-insurance policies would immunize countries against external shocks and contagion, allowing emerging markets to decouple from the faltering core, or so the story went. Again, do not miss the irony that there should be any need to self-insure against the supposedly manifold benefits that capital account liberalization was meant to bestow on emerging markets according to the , Washington Consensus،.

A look at the group of countries that was hit hard enough by ssudden reversals in private capital flows to need to call in the IMF for their rescue certainly provides support for the self-insurance idea, since these were invariably countries that had large current account deficits when global crisis struck, particularly central and eastern European (CEE) and Commonwealth of Independent States (CIS) countries. ${ }^{8}$

Table I: Self-insurance on the rise since the late Ig9os

\begin{tabular}{|c|c|c|c|c|c|c|c|c|c|}
\hline & \multicolumn{5}{|c|}{ Current account balances (\% of GDP) } & \multicolumn{4}{|c|}{ Foreign reserve holdings ( $\%$ of GDP) } \\
\hline & 1995 & 2000 & 2005 & 2009 & & $1995^{(\mathrm{I})}$ & $2000^{(2)}$ & 2005 & $2008^{(3)}$ \\
\hline Argentina & -2.0 & -3.1 & 2.6 & 2.8 & Argentina & 6.4 & 9.7 & 17.7 & I4.I \\
\hline Brazil & -2.4 & -3.8 & I. 6 & $-\mathrm{I} .5$ & Brazil & n.a. & 6.5 & 6.I & II. 8 \\
\hline China & 0.2 & I.7 & 7.2 & 5.8 & China & n.a. & n.a. & 37.2 & 43.5 \\
\hline Colombia & $-4 \cdot 4$ & 0.8 & $-\mathrm{I} .3$ & -I. 8 & Colombia & $8 . \mathrm{I}$ & $9 \cdot 3$ & IO.I & 9.8 \\
\hline India & $-\mathrm{I} .6$ & -I.O & -I.3 & $-2 . \mathrm{I}$ & India & $7 \cdot 4$ & $9 \cdot 3$ & 19.2 & $2 \mathrm{I} .2$ \\
\hline Indonesia & -3.0 & 4.8 & O.I & 2.0 & Indonesia & n.a. & 17.4 & I2.I & IO.I \\
\hline Korea & $-\mathrm{I} .6$ & 2.3 & I. 8 & 5.1 & Korea & n.a. & 20.4 & $24 \cdot 9$ & 32.4 \\
\hline Malaysia & -9.6 & 9.0 & I5.0 & I6.7 & Malaysia & n.a. & $32 . \mathrm{I}$ & 50.8 & 4I.3 \\
\hline Mexico & -0.5 & -3.0 & -0.5 & -0.6 & Mexico & n.a. & 6.1 & $8 . \mathrm{I}$ & 7.8 \\
\hline Philippines & -2.6 & -2.9 & 2.0 & $5 \cdot 3$ & Philippines & n.a. & 22.0 & I8.7 & 22.4 \\
\hline Poland & 0.6 & -5.8 & $-\mathrm{I} .2$ & - I. 6 & Poland & Io.8 & I6.0 & I4.O & I8.5 \\
\hline Russia & 2.2 & I8.0 & II.O & $3 \cdot 9$ & Russia & 5.5 & IO.8 & 23.8 & $25 \cdot 7$ \\
\hline South Africa & $-\mathrm{I} .7$ & -O.I & -3.5 & -4.0 & South Africa & $3 \cdot 3$ & 5.7 & 8.4 & $\mathrm{I} 2.3$ \\
\hline Turkey & -2.4 & -3.7 & -4.6 & -2.3 & Turkey & 6.I & 8.8 & I0.9 & IO.2 \\
\hline
\end{tabular}

Note: (I) 1996 in the case of India. (2) 200 in the cases of: Brazil, Indonesia, Korea, Malaysia, Mexico, and the Philippines. (3) 2009 in the cases of Korea and Poland.

Source: IMF (IFS)

8 IMF crisis programs have lent support to Armenia, Belarus, Bosnia and Herzegovina, Costa Rica, El Salvador, Georgia, Guatemala, Hungary, Iceland, Latvia, Mongolia, Pakistan, Romania, Serbia, and Ukraine; see IMF (2009a). Current account deficits in countries ranged from 5 to over 20 percent of GDP. 
Of more interest in assessing the effectiveness of self-insurance are therefore countries that got away without IMF help. This section will focus on a select group of I4 leading emerging economies, namely Argentina, Brazil, China, Colombia, India, Indonesia, Korea, Malaysia, Mexico, the Philippines, Poland, the Russian Federation, South Africa, and Turkey. ${ }^{9}$ Table I shows current account positions and reserve holdings for this sample starting in 1995 . Figure 6 revealed the aggregate shift from current account deficit to surplus following the Asian crisis of the late I990s. In Latin America the shift was somewhat delayed following the crises in Argentina and Brazil of the early 20oos. Prior to the global crisis current account positions of sample countries were generally in surplus or small deficit. In this regard untypical were Poland, South Africa, and Turkey, countries that saw their current account deficits rise to 5 to 7 percent of GDP just before the global crisis, but in the event did not need to draw on IMF help. In general, reserve holdings soared in the 2000 (and net international investment positions not shown here improved too), in line with the aggregate trends captured in Figure 6. Investigating individual country experiences, the aim in this section is to identify both common features, as well as differences, in initial positions and policy responses, and to scrutinize to what extent self-insurancer really proved effective for these countries.

Starting with Argentina, the country's current account turned into surplus in the aftermath of the 200 I crisis and the positive balance was little affected by the crisis as both exports and imports slumped in the fourth quarter of 2008. A relatively small financial account surplus in the years 2005-07 bolstered Argentina's reserve accumulation before turning sharply negative in 2008. As to the composition of capital flows, foreign direct investment (FDI) held up well until the second quarter of 2009 and cross-border banking flows, too, were little affected throughout the crisis. By contrast, portfolio debt inflows reversed sharply in mid-2007 and (the less important) portfolio equity flows followed suit in early 2008. In Argentina's case, other investments by nonbanks proved most volatile, with outflows accelerating sharply in 2007 and inflows drying up in the last quarter of 2008. Some limited reserve deployment accompanied the peso's plunge.

After turning positive following the 2002 crisis, Brazil's current account again deteriorated in 2007 and turned negative in 2008 , largely due to a soaring negative income balance on the current account and a sharp real appreciation. Capital inflows and reserve accumulation continued at a high rate until the fall of 2008 . Then, in the final quarter of 2008 , while FDI flows held up well until year end, portfolio inflows and other investment flows were caught up in the sudden stop that hit Brazil at the time. Deleveraging of cross-border banking flows had started in the third quarter of 2007 , but accelerated sharply in the final quarter of 2008. There was some deployment of reserves in the final quarter to counter the real's plunge.

9 My choice of countries was guided by the criteria of global relevance and data availability. In particular, selected countries are largely representative for emerging Asia and Latin America, regions that fared far better than CEE and CIS countries. G-2o Emerging Markets quarterly data from the IMF's International Financial Statistics is not available for China and Saudi Arabia. In the former case, I made use of data from China's State Administration of Foreign Exchange (SAFE) and the People's Bank of China (PBC) instead. Among this sample, the IMF's newly introduced 'Flexible Credit Line facility provided insurances for Mexico, Colombia, and Poland; see IMF (2009b). 
Figure 7: Crisis impact on Argentina's financial account

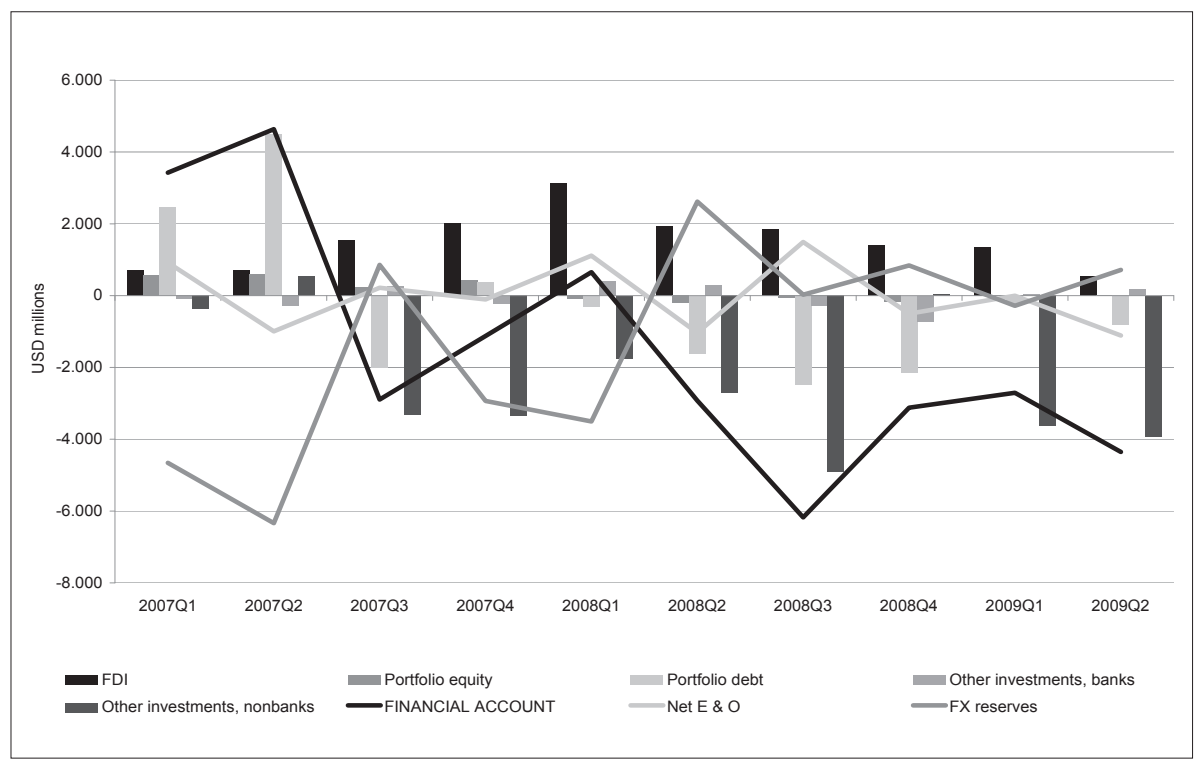

Notes: Net flows

Source: IMF (IFS)

Figure 8: Crisis impact on Brazil's financial account

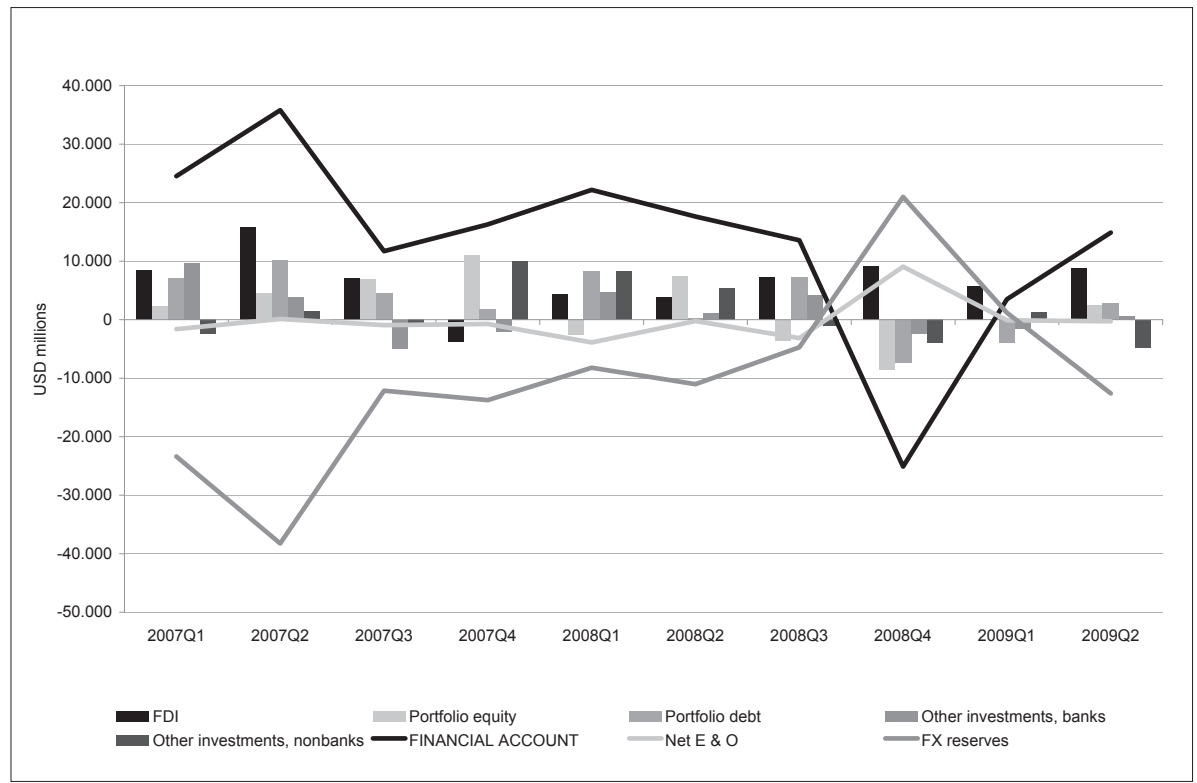

Notes: Net flows

Source: IMF (IFS) 
Starting in 1994, China has maintained both a US dollar peg and current account surplus position. The country's current account surplus ballooned in recent years, rising from US\$ 35 billion in 2002 to US $\$ 426$ billion in 2008 . The global crisis then took a severe hit on China's trade; goods exports plunged from US $\$ 764$ billion for the second half of 2008 to US \$ 52I billion in the first half of 2009, nearly halving China's trade and current account surpluses. When viewed relative to its large trade flows and huge stock of reserves (making up some 80 percent of China's net foreign assets), the impact on China's comprehensively managed financial account proved more limited though. Traditionally, capital account management in China has strongly favored direct investment, therefore making up the bulk of the country's foreign liabilities while restricting other forms of inflows (Ma/McCauley 2007). In recent years China has started liberalizing capital outflows to assist in keeping the financial account in check and thereby containing soaring reserve accumulation. While not apparent from half-yearly SAFE statistics, PBC statistics show reserve losses in October 2008, as well as in January - February 2009. Following a gradual 20 percent renminbi appreciation vis-à-vis the US dollar since July 2I, 2005, China has kept the renminbi stable to the US dollar since August 2007, officially moving to a managed float vis-à-vis a basket of currencies in July 2005 .

Figure 9: Crisis impact on China's financial account

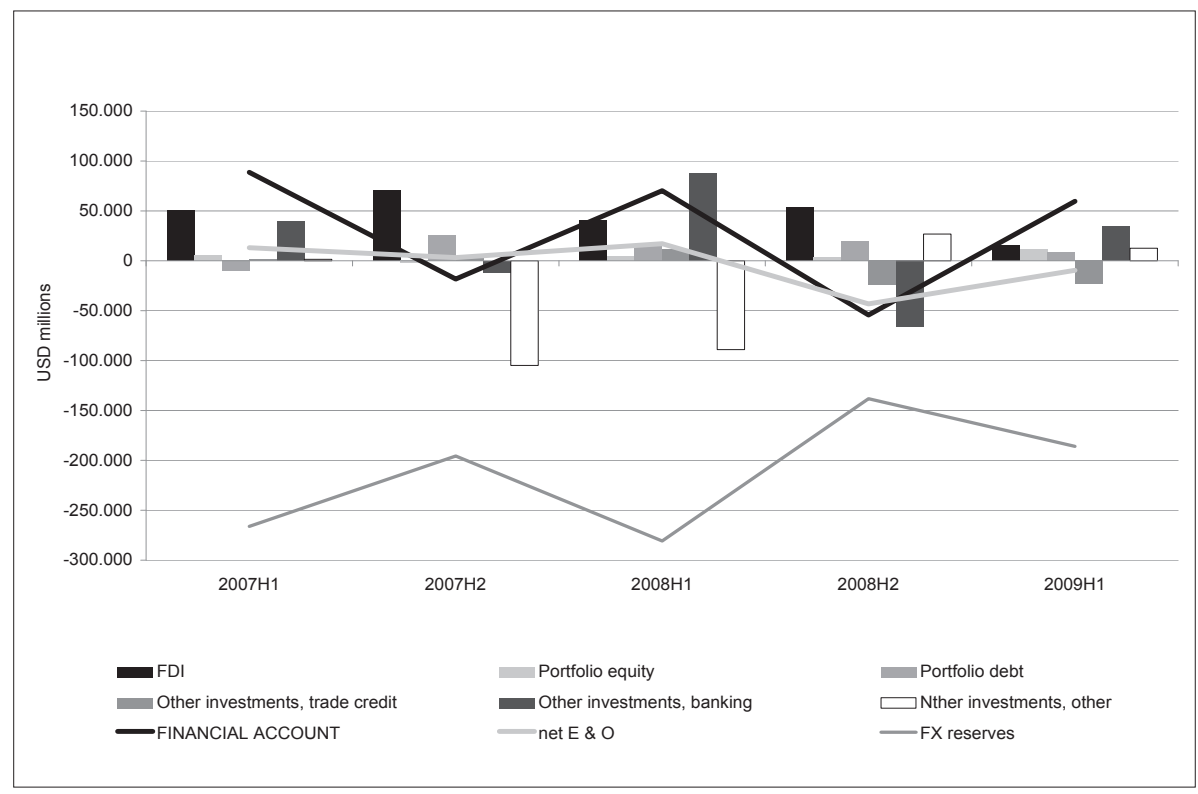

Notes: Net flows

Source: SAFE

Colombia ran current account deficits for much of the I990s and again since 200I. Current account deficits increased strongly after 2004, but capital inflows surged even more, allowing reserve accumulation at a moderate rate. Capital inflows fell off in the course of 2007 and, 
after some recovery in the first three quarters of 2008, they declined again in the final quarter of that year. The outstanding facts are that direct investment inflows held up well through 2008, while nondirect investment flows only play a relatively minor role in Colombia's case. Reserve deployment occurred on a small scale in the final quarter of 2008 , while the Colombian peso saw quite a marked depreciation from its peak in the spring of 2008 until year-end.

Figure Io: Crisis impact on Colombia's financial account

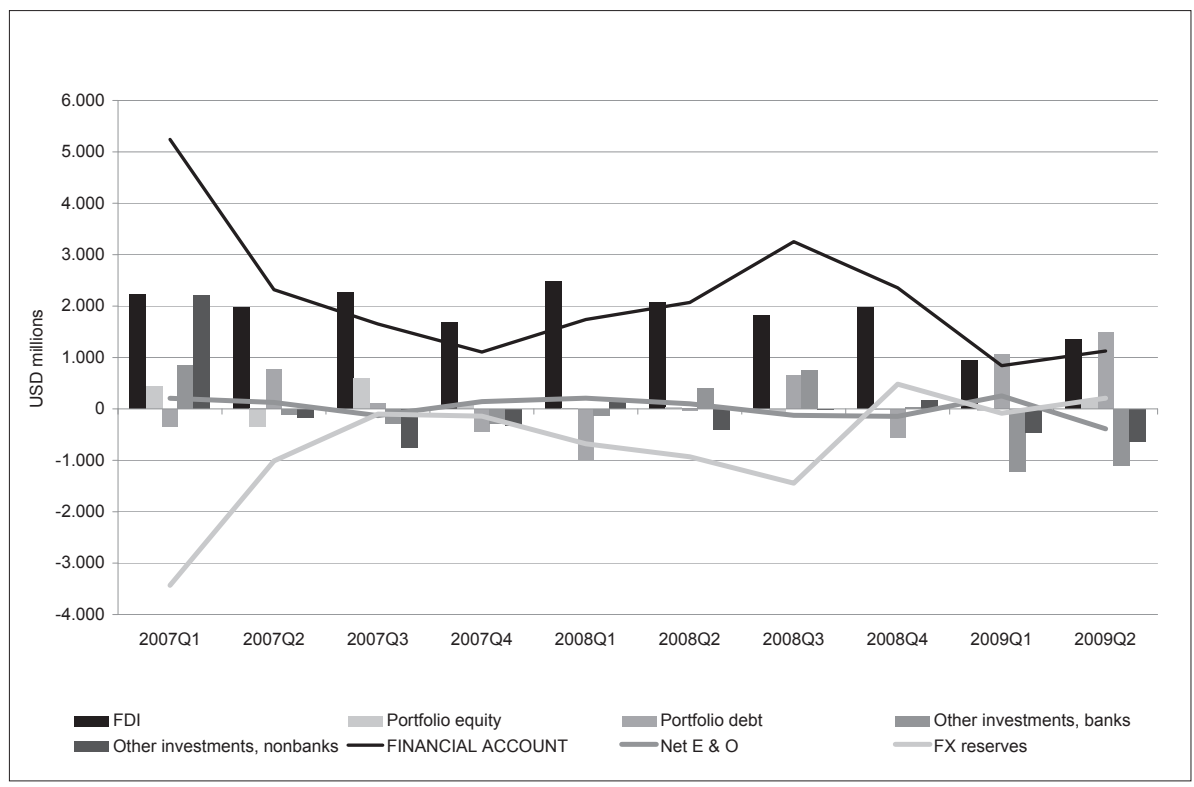

Notes: Net flows

Source: IMF (IFS)

India's current account was in deficit during the I990s, in surplus in the years $2000-04$, and again in deficit thereafter. Following a sharp commodity-driven rise in 2008 , the global crisis then turned the current account deficit into a small surplus in first quarter of 2009. India had gradually opened its financial account to capital inflows (excluding portfolio debt; see Mohan 2009) and experienced a surge in inflows in 2007 before being subjected to a sudden reversal in 2008 . Portfolio equity inflows reversed in the first quarter of 2008 , followed by other investment inflows by nonbanks in the second quarter. In the final quarter of 2008, cross-border banking flows were then caught up in the global banking deleveraging, although to a relatively small extent. Meanwhile, direct investment inflows fell back from their alleviated $2008 \mathrm{HI}$ level. In the second half of 2008 the authorities deployed reserves to contain the rupee's plunge.

Indonesia had current account surpluses since I998. Both exports and imports suffered similar compression in the context of the crisis. Following financial account deficits from I998 until 2005, the financial account registered surpluses in 2006 - 07, although small com- 
Figure II: Crisis impact on India's financial account

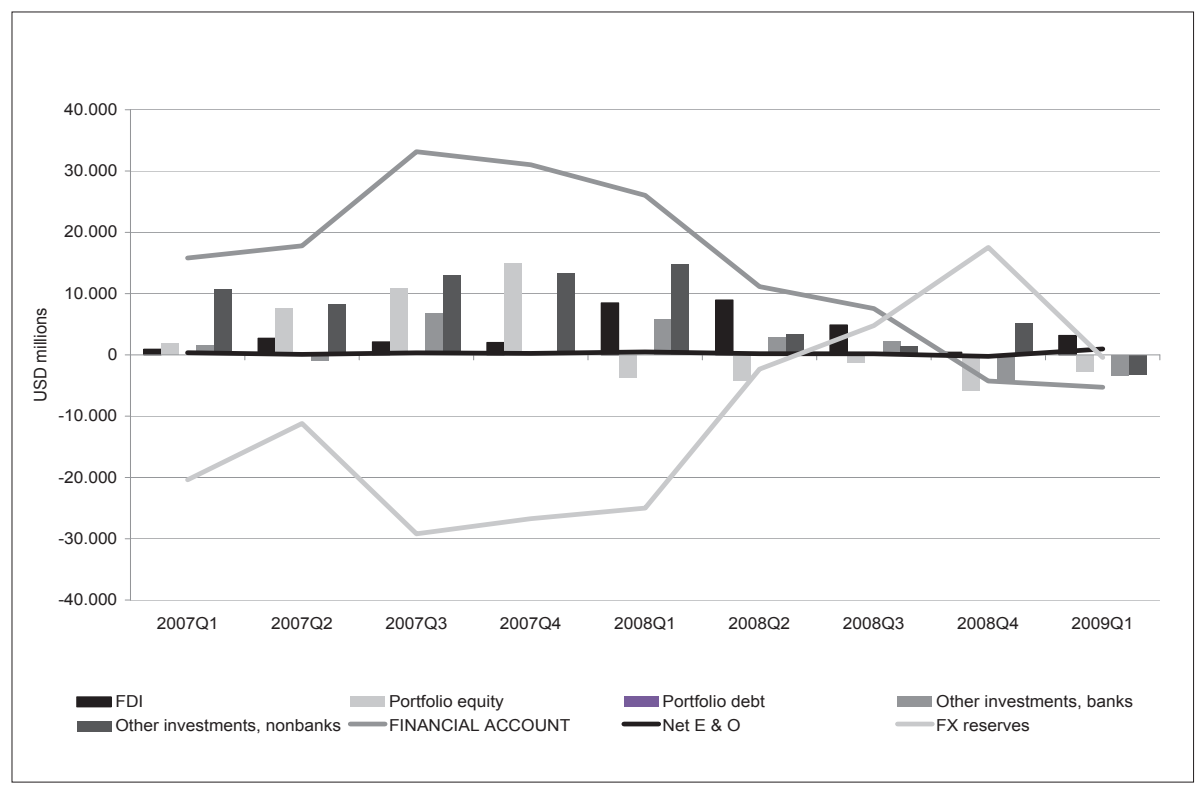

Notes: Net flows

Source: IMF (IFS)

pared to the pre-I997 period. With portfolio equity flows playing only a minor role, reversals in portfolio debt inflows - first in the final quarter of 2007 and again a year later - featured more prominently. As to other investments, outflows by both banks and nonbanks proved more volatile than inflows. Deployment of reserves in the final quarter of 2008 occurred as the rupee's dollar peg gave way to market pressures.

Korea's current account surplus position since 1998 briefly turned into deficit during the first three quarters of 2008 , but quickly reversed into surplus in the final quarter as commodity prices deflated and import compression exceeded the falling off of exports. Portfolio equity inflows experienced a sharp reversal starting in mid-2007 and through 2008 , while portfolio equity outflows and portfolio debt inflows then reversed in the second half of 2008. However, the sharpest reversal occurred in banks' other investment inflows in the final quarter of 2008, when derivative flows also added to Korea's financial account deficit. Sizeable deployment of reserves throughout 2008 did little to contain the won's very sharp depreciation.

Current account surpluses, together with financial account deficits overall resulting in reserve accumulation, characterized Malaysia's balance of payments from 1998 until mid-2008, after which the financial account deficit worsened sharply. Portfolio equity inflows reversed early in the second quarter of 2007 with portfolio debt inflows following suit a year later. Banks' other investment outflows reversed in the second quarter of 2008 , while corresponding inflows reversed in the final quarter. Reserves were deployed as the ringgit depreciated. 
Figure 12: Crisis impact on Indonesia's financial account

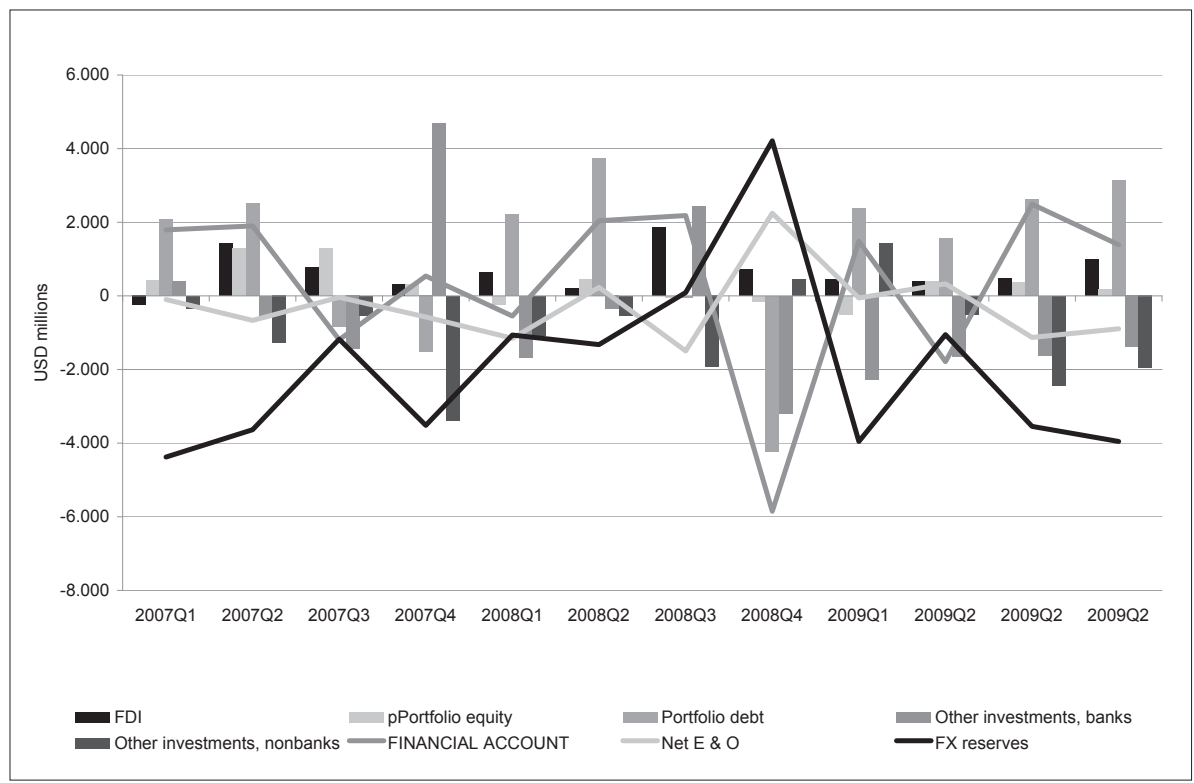

Notes: Net flows

Source: IMF (IFS)

Figure I3: Crisis impact on Korea's financial account

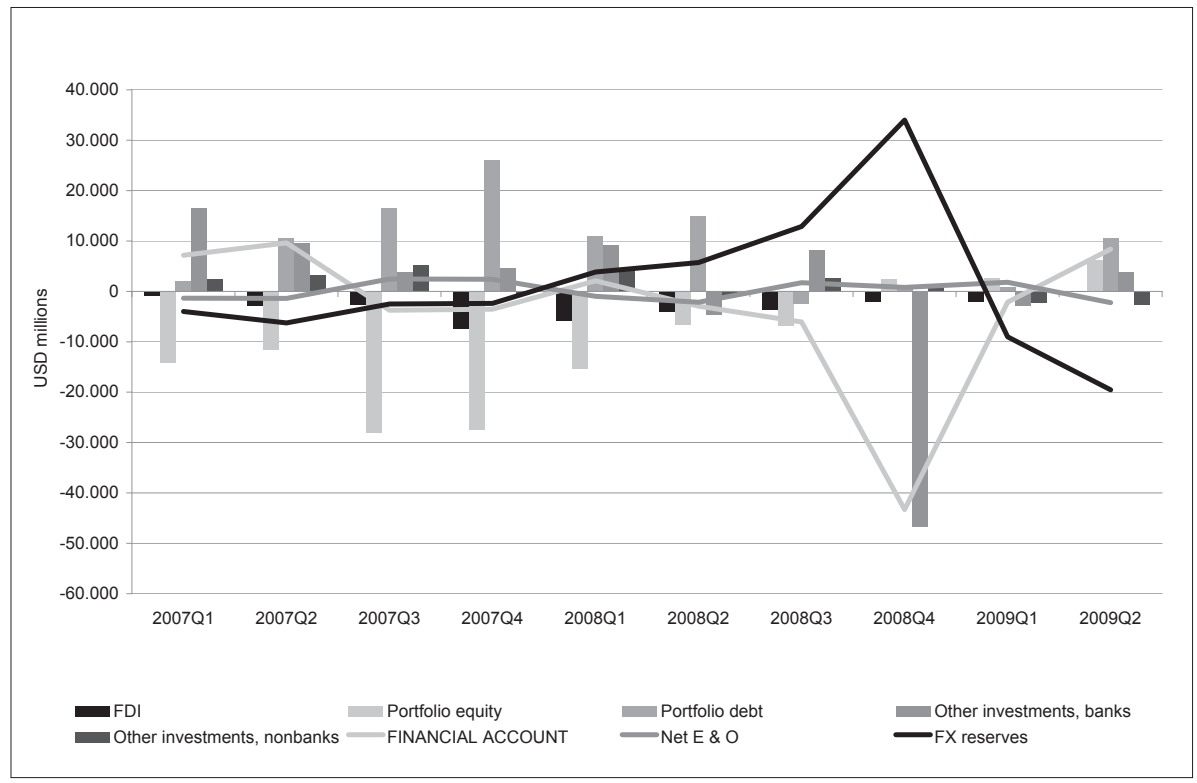

Notes: Net flows

Source: IMF (IFS) 
Figure I4: Crisis impact on Malaysia's financial account

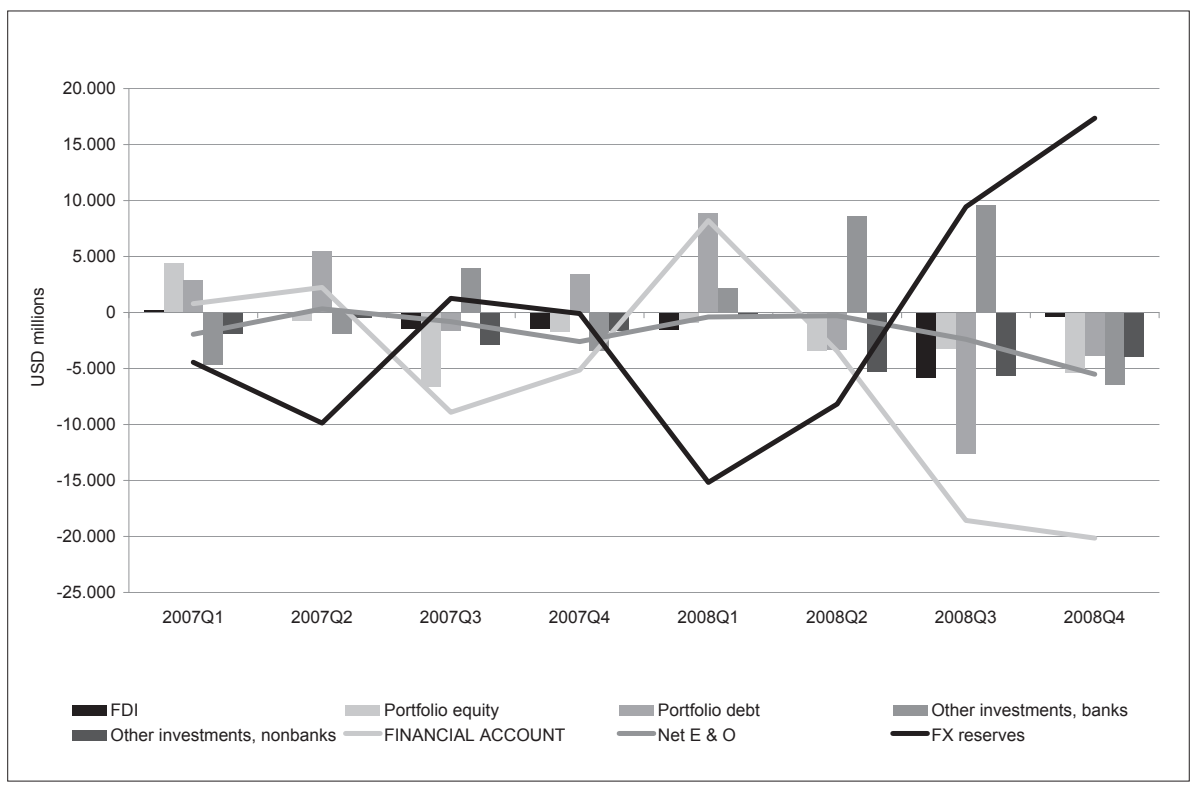

Notes: Net flows

Source: IMF (IFS)

Mexico had a current account deficit for decades that, except for the 1995 crisis, was overcompensated by financial account surpluses except for the year 2006, resulting in generally rising reserves. Volatile portfolio equity inflows registered a sharp reversal to net outflows in the third quarter of 2008. More important portfolio debt inflows then saw a sharp reversal in the fourth quarter of 2008 , which was, however, more than compensated by a conspicuous temporary reversal in the opposite direction in both banks' and nonbanks' other investment outflows occurring in the same quarter. While some small reserve declines had been registered in the third quarter of 2008 as the Mexican peso depreciated together with other emerging market currencies, the financial account deficit arising in the first half of 2009 meant more sizeable reserve deployments, even as the current account improved.

The Philippines had twin surpluses on current and financial account in recent years (including 2007) with correspondingly rising reserves. Portfolio equity inflows reversed in the fourth quarter of 2007 , followed by reversals in portfolio debt in- and outflows in the second quarter of 2008. A similar retrenchment in cross-border engagements of banks' and nonbanks' other investments was seen starting in the fourth quarter of 2007. Other investment flows by nonbanks and banks then saw another temporary shift toward net inflows in the second and third quarters of 2008 , respectively. The financial account turned into a deficit in the final quarter of 2008, with reserve deployment to contain the Philippine peso's depreciation. 
Figure I5: Crisis impact on Mexico's financial account

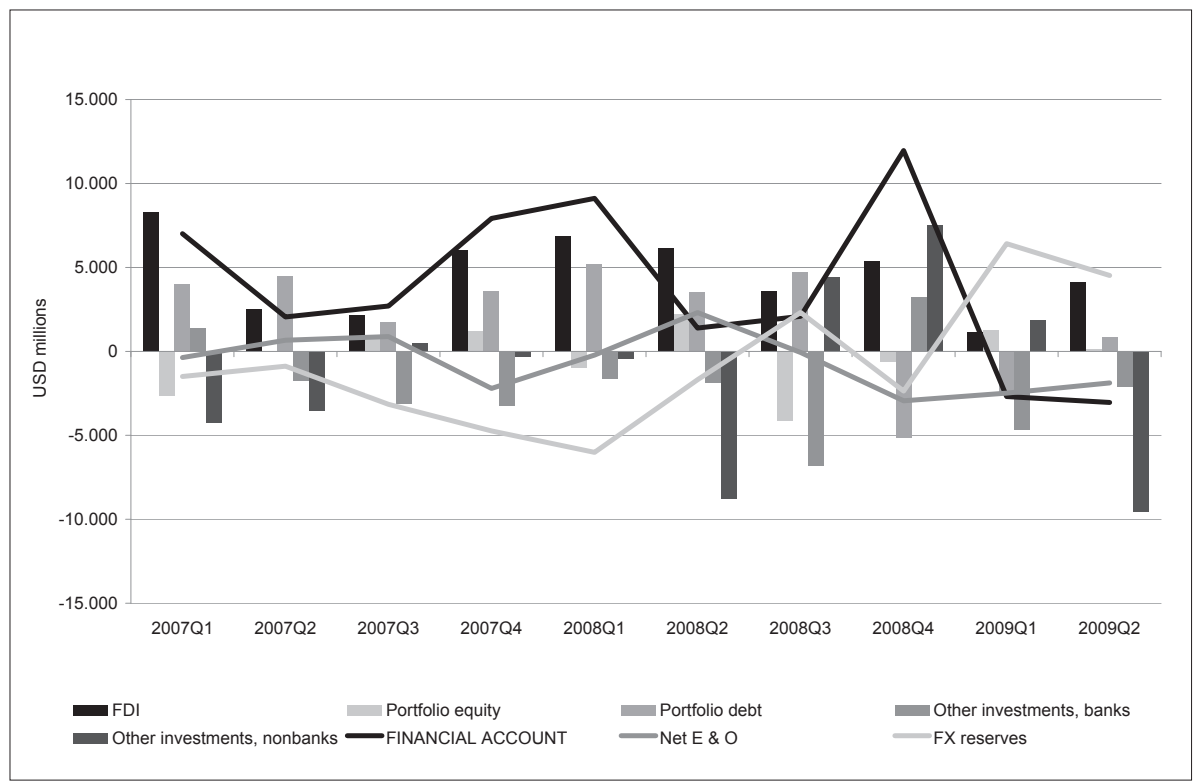

Notes: Net flows

Source: IMF (IFS)

Figure I6: Crisis impact on the Philippines' financial account

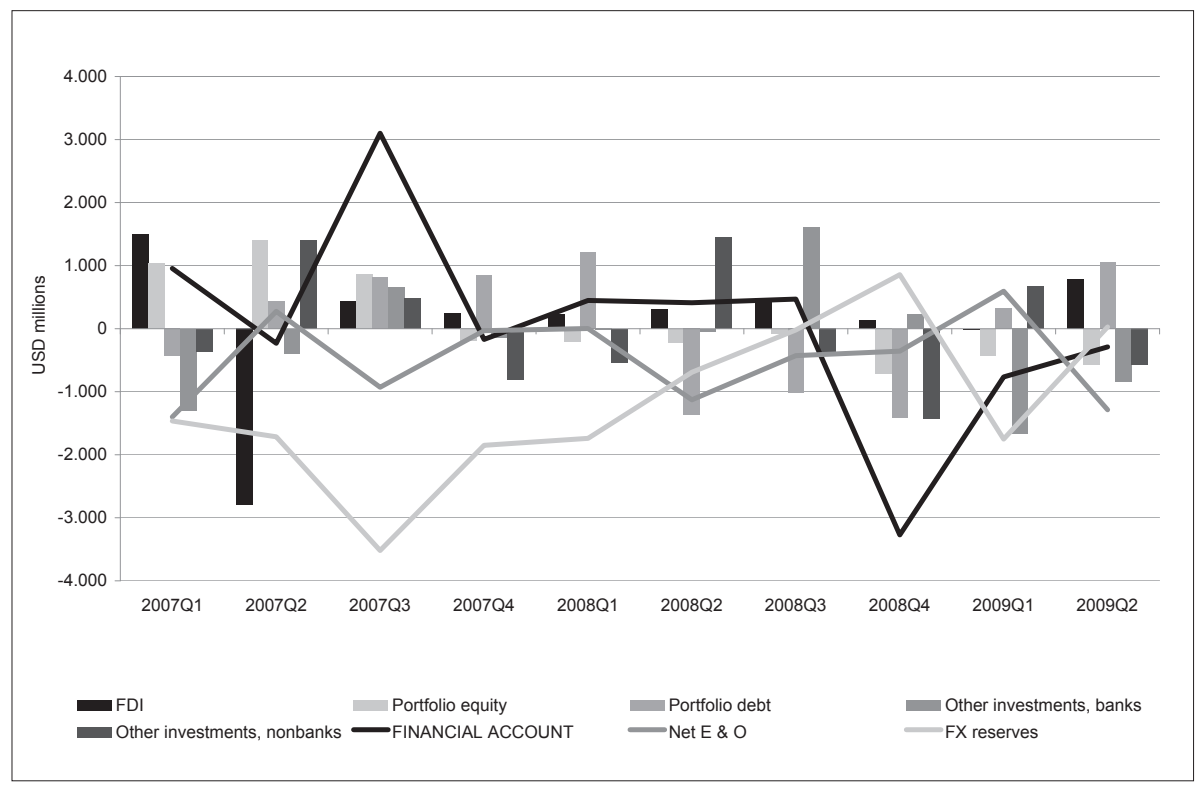

Notes: Net flows

Source: IMF (IFS) 
Poland has generally run current account deficits during its transition process. The deficit had soared after 2006, but trade compression during the crisis delivered a balanced position in the first quarter of 2009. Poland experienced rising capital inflows and reserve accumulations for four quarters starting in mid-2007, followed by a sharp decline in inflows and reserve losses in the second half of 2008. Direct investment inflows declined significantly since mid-2008, but stayed positive. Portfolio equity flows played only a minor role, shifting from negative net flows into positive territory during the first three quarters of 2008 . Heightened volatility befell portfolio debt flows after mid-2007. Rather unusually, banks' other investment inflows even rose in 2008, while the corresponding outflow category shows retrenchment in most quarters since early 2007 , resulting in a sizeable net positive contribution. Nonbanks' other investments registered net inflows except for the first quarter of 2009. Sizeable reserve deployment occurred in the second half of 2008 as the zloty depreciated sharply. Throughout there were large and persistently negative net errors and omissions.

Figure 17: Crisis impact on Poland's financial account

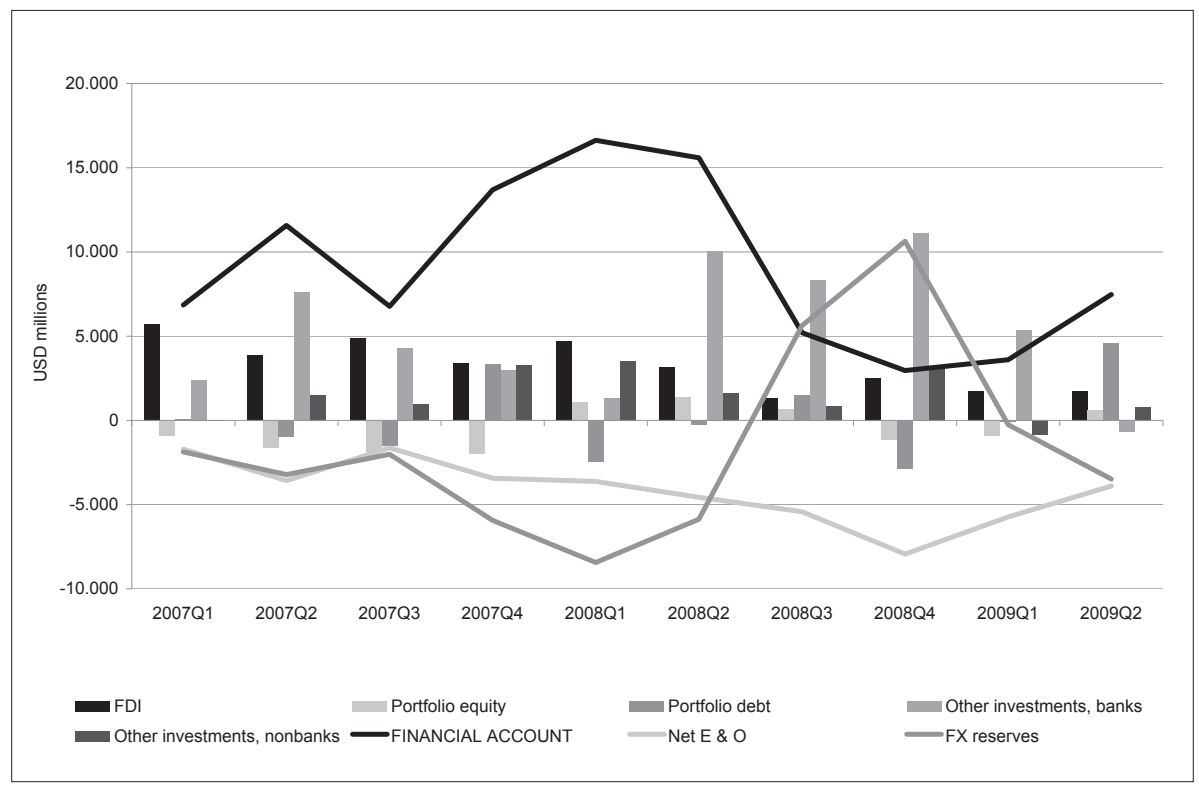

Notes: Net flows

Source: IMF (IFS)

Following the 1998 crisis, Russia saw rising current account surpluses until 2008, helped by the oil price boom. The global crisis and oil-price bust then crushed the surplus after mid2008. Reserve accumulation had been temporarily bolstered as capital inflow liberalization led to a surge in inflows in 2007 . But a sudden reversal then occurred after mid-2008 involving portfolio equity and debt and, especially pronounced, other investment inflows. While direct investment inflows held up fairly well, accelerating direct investment outflows shift- 
ed this category, too, into negative territory in the first half of 2009. Large-scale reserve deployment occurred during three quarters starting in mid-2008 as the ruble plunged sharply.

Figure I8: Crisis impact on Russia's financial account

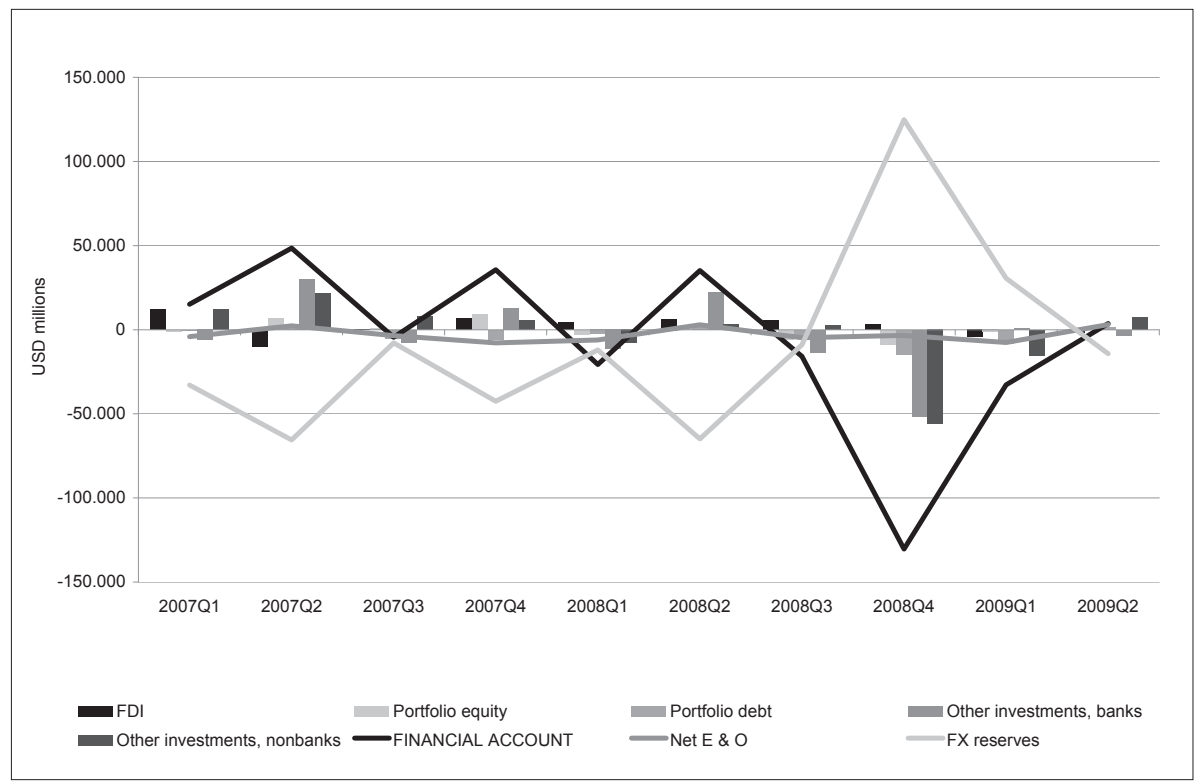

Notes: Net flows

Source: IMF (IFS)

Following small current account surpluses early on in the decade, South Africa ran soaring current account deficits since 2003, which were however more than offset by capital inflows, overall feeding into reserve accumulation at a moderate rate. Trade compression contracted the current account deficit and capital inflows came to a halt in the final quarter of 2008. The sudden stop in capital inflows was dominated by sharp reversals in portfolio equity and debt inflows and rising portfolio equity outflows, especially in the fourth quarter of 2008, with a partial offset coming from banks' other investment flows owing to reversing outflows. All along, direct investment flows held up. Apparently, the South African authorities refrained from deploying reserves as the rand saw one of the sharpest plunges visà-vis the US dollar among emerging market currencies.

Following its latest crisis in the early 20oos, Turkey started running rising current account deficits since 2003 that were more than offset by capital inflows, overall resulting in reserve accumulation at a very moderate scale. Trade compression during the crisis sharply reduced the current account deficit, while a sudden reversal in the financial account started in the fourth quarter of 2008 lasting until the second quarter of 2009 that was accompanied by reserve deployment to contain the lira's plunge. In Turkey's case, the sudden reversal was dominated by banks' other investment inflows in the fourth quarter of 2008 . Port- 
Figure 19: Crisis impact on South Africa's financial account

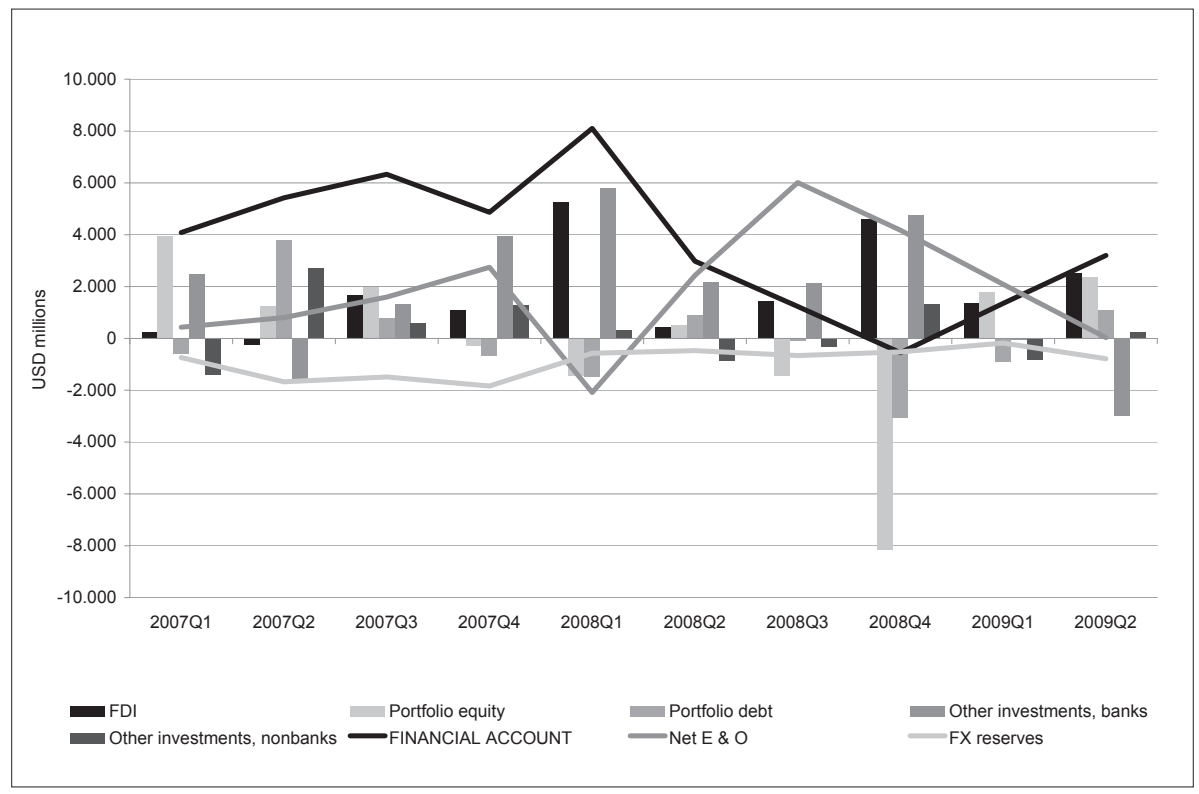

Notes: Net flows

Source: IMF (IFS)

Figure 20: Crisis impact on Turkey's financial account

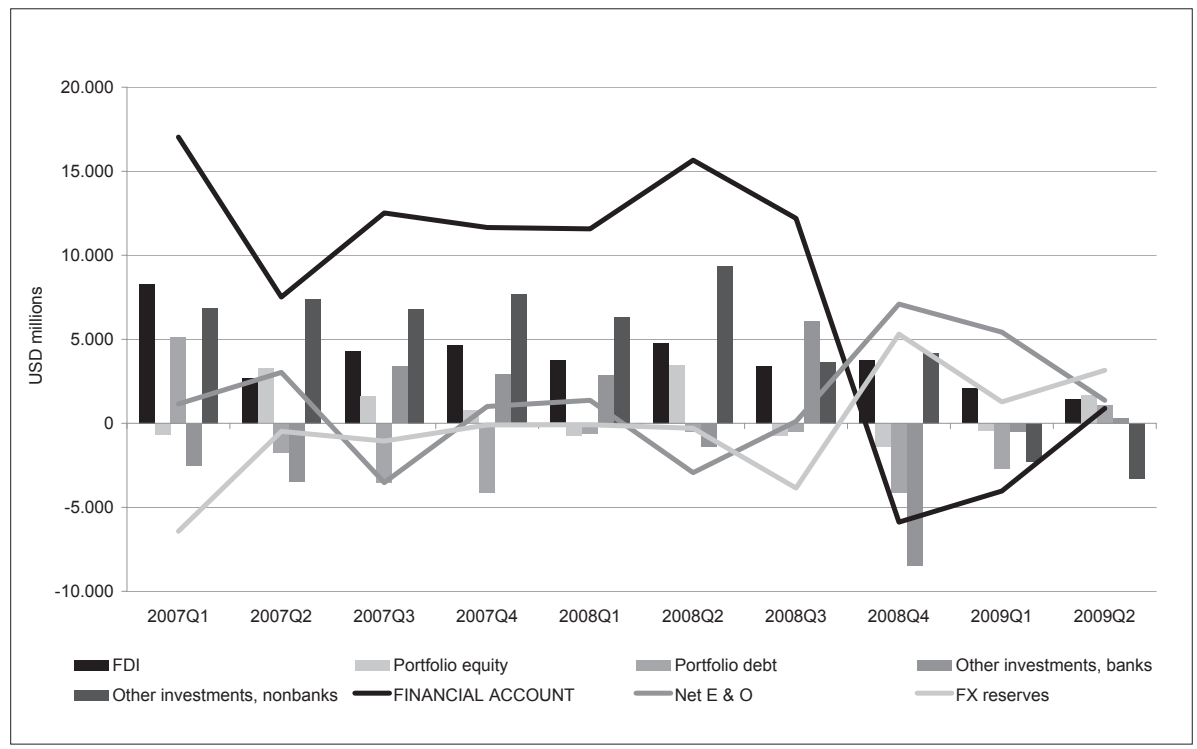

Notes: Net flows

Source: IMF (IFS) 
folio debt inflows had reversed earlier in the second quarter of 2007, while portfolio equity inflows proved rather volatile since 2007 , with a negative contribution to the financial account during the three quarters starting in mid-2008. Finally, in 2009, direct investment inflows too declined markedly.

The overall picture emerging from these findings here confirms that emerging markets experienced the repercussions of the crisis at the core of global finance largely as a common event, a sudden stop or reversal in private capital flows that was hitting countries quite indiscriminately. Self-insurance did neither keep the panic at the core of global finance from reaching peripheral countries only shortly before judged unassailable for lack of any direct exposure to what was suddenly terrifying global investors nor did the involuntary bystanders receive any insurance-like compensation in the event. Being financially integrated means being exposed to financial instabilities hatched elsewhere; without escape or insurance claim foreseen in the contract.

As to the composition of capital flows, the current crisis also confirmed earlier experiences in showing direct investment flows as a relatively stable category whereas other types of flows proved generally far more flighty. While deleveraging of key global banks at the core of global finance (in conjunction with repatriation of portfolio investments from advanced country investors) sent a common shock wave throughout the emerging market universe in the final quarter of 2008, our comparative country analysis reveals variety in the degree of flightiness and timing of nondirect investment flows in particular. All countries experienced sudden stops or reversals in portfolio inflows at some point, but portfolio outflows naturally only played a role in cases that had liberalized this category. Reversals in banks' other investments featured prominently in the cases of Korea, Russia, and Turkey, whereas this category of capital flows acted in a stabilizing way in Malaysia, Poland, and South Africa. Similar contrasts are seen in nonbanks' other investments, including trade credit. These results certainly suggest that it would be worthwhile to study the country-specific conditioning factors that led to these different outcomes. In particular, a cross-country study of differences in bank regulation and supervision and in degree of capital account openness (or management) should reveal useful insights as to how countries can best shield their financial systems other than through self-insurance as such.

Depreciation of emerging market currencies against the US dollar represented another common phenomenon (as already seen in Figure 5 above), a general flight to quality away from emerging markets (and abrupt carry-trade unwinding that also favored the Japanese yen). This was generally true whether countries had a surplus or moderate deficit on their current account. Rare exceptions included China and Saudi Arabia - steadfastly maintaining the US dollar peg under adverse conditions. While currency depreciation may be seen as a relief factor in the context of an export plunge, it must be remembered that depreciation was not the result of deliberate policy choices, but abruptly thrashed upon countries by markets in panic. If depreciation was judged to offer some nifty reprieve on this occasion, perhaps the relevant policy choice was not to make more extensive use of available reserves than was actually the case. But that is mere speculation. What seems more relevant is that general EM currency depreciation followed a period during which emerging market poli- 
cymakers had been challenged by surging capital inflows and currency appreciation. Again, it is rather interesting, if not satirical, that the IMF observed in the quotation further above that the storrid pace of capital inflows was giving rise to concerns at that time. My guess is that the opposite challenge was hardly any more welcome. Arguably, crisis contagion across the emerging market universe followed a surge in capital inflows that was driven by, as well as driving, the decoupling theme in 2007 and until mid-2008 as the global carry-trade received a final massive boost - before its abrupt implosion.

The crisis impact on GDP growth within the sample group varied quite significantly, it was sharpest in Turkey, mildest in India and Indonesia. In most cases the collapse also proved short-lived. In the final quarter of 2009 many countries, led by China, had re-attained fast growth; with Mexico, the Russian Federation, and South Africa lagging the pack. Surely the variation in crisis impact on GDP cannot be solely or even mainly attributed to the extent of self-insurance that countries had taken out. Many other conditioning factors would need to be considered. But that is not the point. The fact that self-insurance worked in the sense that IMF rescue was avoided, typically involving a more or less complete loss of policy space, might send out the message that self-insurance is the way to go, and the more so, the better. This advice would overlook important systemic issues, to be discussed momentarily.

In conclusion, neither initial current account surplus positions nor large FX reserve holdings properly insulated countries from the common external shock. ${ }^{\text {io }}$ We speak of a 'global crisis`, rather than a US or European crisis, precisely because self-insurance did not shield the developing world from the crisis at the core of global finance - as the decoupling hypothesis had held out. Rather, self-insurance strategies merely provided a certain margin of safety that determined, first of all, whether IMF support was needed in the event and, second, the particular country's policy space for implementing countercyclical policies on their own. No doubt these may well be judged as important advantages offered by self-insurance, retrospectively perhaps, especially as seen by countries that failed to take out sufficient self-insurance. But does it really follow that the best advice we might therefore offer in the light of these experiences is that emerging markets should from now on aim at taking out even more self-insurance? ${ }^{\text {II }}$

In my view, it would be rash to jump to that conclusion. While self-insurance (cum neo-mercantilist) strategies have helped self-insuring countries to prevent the occurrence of crises that originate on their home turf, and also to avoid IMF influence and recues. Furthermore, self-insurance may have seemingly turned emerging markets into ssafe and sound investment destinations for advanced country investors, much to their joy of course, at least until some panic befalls them. Yet, it should not be overlooked that the strategy cannot work globally unless somebody out there acts as global >borrower and spender of

Io Similarly, Berkmen et al. (2009) did not find a statistically significant effect of the stock of reserves on growth revisions.

II For instance, Dooley, Folkerts-Landau, and Garber (2009) suggest that the crisis experience might encourage countries in this direction. Subramanian (2008) recommends that India should step up its self-insurance efforts. 
last resort «, thereby selling insurance - on demand - along the way. The point is that there are crucial systemic issues involved here that have to be taken into account. The literature tends to treat the usefulness of self-insurance strategies as separate from certain systemic issues that concern the sustainability of the current international monetary and financial order. ${ }^{\mathrm{I2}}$ In my view, their strong interdependence calls for a joint assessment, which is precisely why the next section is going to approach the whole matter from the perspective of the global self-insurance underwriter.

Do not miss the following irony. Historically, at first the era of financial liberalization produced a surprising proneness for recurrent financial crises among emerging market countries. As the developing periphery learned their lesson and took out self-insurance instead, turning themselves into safe and sound places, financial fragility built up at the advanced core instead. Yet, in the end, as the key reserve currency issuer acting as global insurer became overburdened in meeting the worldwide demand for self-insurance and finally stumbled, emerging market insurees got hit again anyway. In other words, whatever may seem to be the case individually, self-insurance has not reduced global systemic risk, but merely transferred risk from one party, emerging markets, to another, the United States - whose role as key reserve currency issuer (and self-insurance underwriter) is the subject of the next section.

\section{Systemic issues: \\ Global imbalances, the US dollar, and rebalancing}

The point is that a general tendency among countries to seek protection (or self-insure) by maintaining a competitive exchange rate vis-à-vis the US dollar, through running up current account surpluses and accumulating soaring foreign exchange reserves (predominantly denominated in US dollars), has important systemic implications. In particular, if everybody pushes exports and aspires to accumulate dollar reserves, strong deflationary forces arise in the system as a whole. Luckily, under the prevailing de facto international US dollar standard, global liquidity is not physically constrained as in the case of gold, but generally depends on the evolution of the US balance of payments over time, as well as on US macroeconomic policy decisions at critical junctures. In principle, there are three sources of US dollars made available to the world economy: US current account deficits, private US capital outflows, and official US lending.

It is therefore not clear that US current account deficits inevitably pose a risk to global stability. Much depends on the demand for US assets, global liquidity in particular. The point was made forcefully by the authors of the >Bretton Woods II (BWII) hypothesis‘, hypothesizing in their influential Essay on the Revived Bretton Woods System that global imbalances featuring a quasipermanent US current account deficit may be sustainable (Dooley et al. 2003). In this view, global current account imbalances reflected a symbiosis of

I2 Insightful readings include: D'Arista (2007-08), Kregel (2004 and 2008), Ocampo (2007-08), Zhou (2009), for instance. 
interests among deficit (United States) and surplus (developing world) countries. The developing world's interest is to sell its products in the large US market as a way of stimulating employment growth and development. The US economy, on the other hand, is flexible enough to tolerate the resulting quasi-permanent drag on US income growth, given its comparative advantage in creating safe assets that the periphery wishes to accumulate for precautionary reasons.

While we have a lot of sympathy with the chosen perspective, placing the global monetary and financial order right at the center of an analysis of global iimbalances that are actually interpreted as a balanced situation, the BWII hypothesis fatefully ignored that the domestic counterpart to the US's external deficit was based not on (safe) public debts, but on (toxic) private debts, mortgage debt in particular. Skepticism regarding soaring household indebtedness and the implications for the solvency of lenders ended the party when underlying collateral values stopped rising in 2006. In essence, as foreign official authorities came to hold a rising share of the outstanding stock of US Treasuries, US consumer spending was fired by households taking on ever more debt relative to income. While falling interest rates helped keep the private debt burden in check to some extent, trends like these can clearly not continue forever (as the Levy Institute's periodic Strategic Analysis warned; see Godley et al. 2007, for instance).

We can clearly see here how the world monetary and financial order nurtured the US consumer in its role as >borrower and spender of last resort ‘. Over the I990s, domestic demand stagnation became entrenched in Japan, Germany, and core Euroland. In the aftermath of the $1997-98$ Asian crisis, increasing numbers of developing countries began seeking safety in pursuing current account surplus rather than deficit positions. China represents a special case within this group. China had pegged the renminbi to the US dollar back in I994. China's current account surplus really only soared since 2003 (Bibow 2007). Oil producers then turned into another important group of current account surplus countries and dollar investors in the final years of the global boom until mid-20o8.

With much of the rest of the world becoming ever keener to export and accumulate dollars, systemic deflationary forces mounted that hit the domestic economy of the key reserve currency issuer by putting downward pressure on wages and prices in general. Given the Federal Reserve's dual mandate of maintaining price stability and high employment, the Fed was forced to ease its policy stance sufficiently to meet its mandate. Monetary policy encourages private spending by lowering interest rates, easing credit, and boosting asset prices. The Fed battled the jobless recovery following the 200 r recession by keeping rates at low levels for a sustained period of time. Rising household indebtedness seemed fine as long as net worth kept on rising, too - as it did as long as the housing boom lasted. As the rest of the world took out ever more self-insurance, US households' balance sheets became increasingly leveraged and fragile.

Do not overlook that the argument put forward here contrasts in important ways with the iglobal saving glut hypothesis`. Bernanke (2005) argues that 
"over the past decade a combination of diverse forces has created a significant increase in the global supply of saving - a global saving glut - which helps to explain both the increase in the US current account deficit and the relatively low level of real long-term interest rates in the world today."

Of course even the notion of a saving glut as such seems rather suspicious from a Keynesian perspective. This suspicion is confirmed when Bernanke goes on and asserts that

»in practice, these countries increased reserves through the expedient of issuing debt to their citizens, thereby mobilizing domestic saving, and then using the proceeds to buy US Treasury securities and other assets. Effectively, governments have acted as financial intermediaries, channeling domestic saving away from local uses and into international capital markets« (Bernanke 2005; italics added).

This last statement clearly reveals loanable funds theory as the theory of interest behind Bernanke's conjectures about a perceived global saving glut and how that glut supposedly depressed interest rates. Following the classical vision of saving as leading and somehow financing investment, Bernanke's saving glut idea presumes that those rexcess savings in the developing world are already there, waiting to be collected (through national debt issuance) and then invested (in US Treasuries), with developing world governments as intermediaries channeling the saving from poor to rich through international capital markets.

While Bernanke's intuition about the relevance of foreign policies in inducing certain developments in the United States may not be altogether wrong, it is important to see exactly how certain market mechanisms and policy adjustments come into play. Bernanke singledout financial crises in emerging markets as inducing the observed shift in developing-world current account positions and the related spurt in reserve accumulation. In practice, the said policy shift meant that crisis countries, following currency depreciation, made it their priority to maintain a competitive exchange rate vis-à-vis the US dollar, paired with an eagerness to add to their depleted dollar reserves as a precaution or sself-insurancer. To think of any saving glut emerging here that would depress interest rates is a ınonsense theory`, as Keynes explained in his General Theory. Instead, as was described above, for the United States as a trade counterparty, such behavior, and the corresponding upward pressure on the US dollar it gives rise to, produces deflationary forces in the domestic economy. The resulting weakness in US labor markets and downward pressures on wages and prices in general will induce the Federal Reserve to ease interest rates as a policy response.

The essential point is that it is not any saving glut that depresses interest rates in any imaginary (classical) capital market, but deficient demand in US product and labor markets - arising from other countries' export-oriented (cum self-insurance) growth strategies - that triggers low interest rate policies from the key global reserve currency issuer. From a liquidity preference theoretical perspective, low US interest rates resulted from the Federal Reserve's expansionary policy stance and financial markets that went along with it, rightly perceiving vastly expanded global supply potential and a lack of inflationary pressures in labor markets. 
On top of US current account deficits as the first source of global liquidity, there is a second source coming into play here, too: private capital outflows. Low Federal Reserve interest rates encouraged private US capital outflows and dollar weakness. Amplified by capital outflows, the resulting global dollar glut transmitted the easy monetary policy stance set at the center to the global economy. Or, rather, other countries faced the choice of either following suit or seeing their currencies appreciate. A popular intermediate course featured reserve accumulation to maintain a competitive exchange rate and continued reliance on export-led growth. In this way, the global dollar glut sourced from both US current account deficits and private capital outflows sponsored the record five-year global boom of 2003-07.

Figure 2I: Reversal of private outflows ends dollar glut

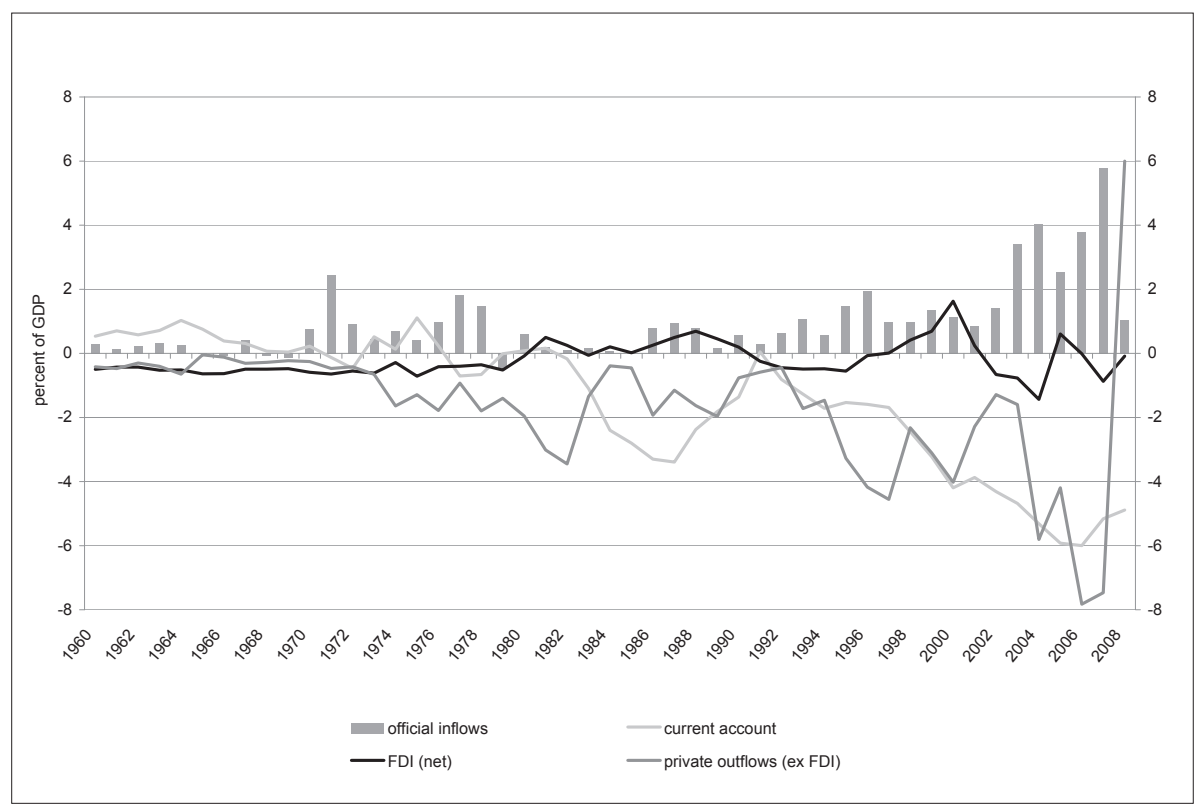

Note: Official inflows are own estimates based on COFER data

Source: BEA, IMF

All went well as long as it lasted. As the global boom saw emerging markets building up strong fundamentals and becoming ever more attractive destinations for private capital inflows, reserve accumulation (i.e., soaring official inflows into the United States, in particular, as seen in Figure 6) was an important counterpart flow (or sponge) to the global dollar glut. Alas, after mid-2008 the global dollar glut suddenly turned into a dollar shortage the key in transmitting the crisis at the center of global finance globally. Figure 2I reveals a conspicuous reversal in other private capital outflows from the United States. Notably, as nonbanks' >other outflows began to reverse sharply in the third quarter of 2007 , this was at 
first partly compensated by banks' >other $<$ outflows. ${ }^{13}$ A global dollar shortage then emerged in mid-20o8 as massive deleveraging by global banks set in.

Figure 22: From dollar glut to dollar shortage.

Official dollar lending of last reserve triggered as nonbanks reverse lending

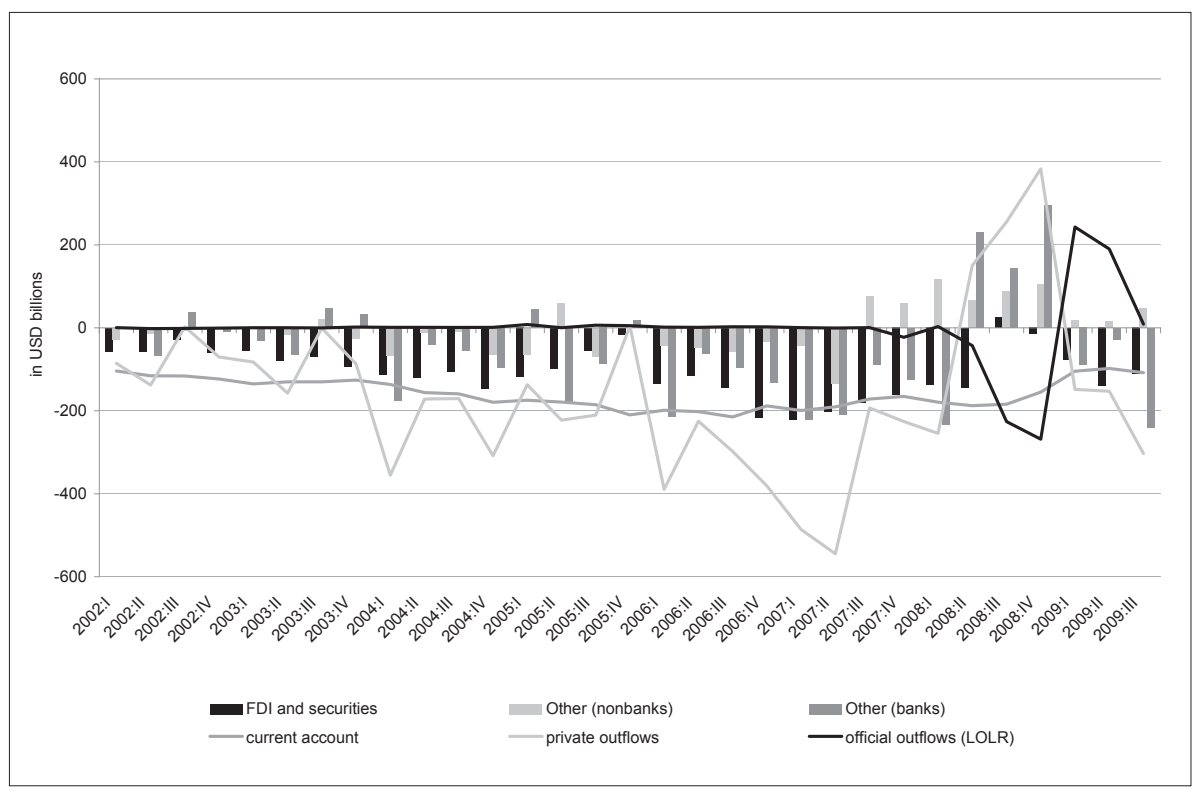

Source: BEA

Figure 22 illustrates the third source of global dollar liquidity in action: official US outflows. In the second half of 2008, >lending of last resort through Federal Reserve swap lines with other central banks filled the gap created by bank deleveraging and dislocations in money markets. In the first quarter of 2009 these offsetting measures and trends again reversed direction as the situation began to calm and normalize. ${ }^{14}$

It is important to reemphasize here that the developing world was largely hit as innocent bystanders by a crisis at the center of global finance, a crisis nurtured by advanced economies. We argued above that the BWII hypothesis correctly diagnosed that developing countries were keenly accumulating safe assets (US Treasuries, in particular), but that BWII ignored that US spending was actually sponsored by unsafe assets fueling the US property

I3 In the IMF's classification scheme, ’other assets are the residual investment category, including trade credit, loans, currency, and deposits.

I4 While large, global banks could also access the Federal Reserve's liquidity fountain directly through their US branches, provided that they held adequate collateral in that location, smaller banks had to take the indirect route involving the international swap grid between the US Fed and other central banks. 
boom. We also argued that Bernanke was wrong in suggesting that foreign Treasury purchases sourced from some imaginary ssaving glut depressed interest rates and thereby induced the US property boom. Instead, we argued that low interest rates were essentially the result of easy Federal Reserve policies ${ }^{15}$ prompted by weakness in US labor and product markets - stemming not least from policies pursued in the rest of the world.

I do not just mean here the demand policies pursued by other advanced, as well as developing, countries. For while US financial regulators and supervisors surely blundered in letting home mortgage finance get out of control, European financial regulators and supervisors are equally to blame for letting European banks off the leash in their international adventures. In their investigation of the US dollar shortage in global banking, McGuire and von Peter (2009) highlight the aggressive global business expansion of European banks in the $2000-07$ period, especially Swiss, Dutch, French, German, and UK banks.

"In aggregate, European banks' combined long US dollar positions grew to more than US $\$ 800$ billion by mid-2007, funded by short positions in pounds sterling, euros, and Swiss francs" (McGuire/von Peter 2009: II).

Their investments featured large exposures to US mortgage credit risk and were mainly long term. Their funding was mainly through money markets, also exposing them to roll-over (liquidity) risk. ${ }^{16}$ Innovative kinds of risk management principles must have guided bank managers in their yearning for yield (and big bonuses). As European financial supervisors were dozing away, their supervisees' leveraged US mortgage engagements first helped to compress credit spreads during the housing boom. Then, as the boom turned bust, European banks were immediately found at the center of what became a global financial crisis as turmoil was not contained locally where fragility had been nurtured. ${ }^{17}$ Through deleveraging by global banks and distress selling in asset markets all around by global investors from advanced countries, the crisis spread to the developing world.

I5 In view of the Federal Reserve's mandate it is not clear that the monetary policies of the Federal Reserve as such deserve blame - which is not to suggest change to that mandate.

I6 In this context, Baba, McCauley, and Ramaswamy (2009) analyze the role of US dollar money market funds in the crisis. They find that up to August 2008 money market funds received safe heaven inflows that helped the funding of non-US banks. However, following Reserve Primary Fund's >breaking-the-buck event caused by the Lehman failure, a wholesale run on money market funds cut off non-US banks' funding from this source. As liquidity demand shifted away from riskier commercial paper (CP) and bank certificates of deposit (CD) toward Treasuries and out of money market funds into bank deposits, they conclude that »if US banks received the deposits while European banks repurchased their $\mathrm{CP}$ and $\mathrm{CD}$ s, then the latter needed to bid in the already strained interbank market." (Baba et al. 2009: 73) See also ECB (2009).

I7 Bibow (2009c) argues that apart from Europe's pivotal role in the crisis at the center of global finance, which itself made the crisis an internal crisis from the start, Europe was also simultaneously hit by other, properly homegrown crises stemming from imploding intra-Euroland and intra-EU imbalances. Moreover, Euroland's lack of proper policy defenses made the supposed island of stability، a drag on global growth. 
In conclusion, widespread reliance on self-insurance strategies through the BWII model has not reduced global systemic risk, but merely transferred risk from EM insurees to the key reserve currency issuer acting as global insurer. Ironically, the crisis at the core of global finance has both once again underlined that emerging markets have every reason to desire taking out self-insurance, while also illustrating that only limited protection is actually obtainable in this way against the unintended consequences of unfettered global finance.

\section{Lessons from the crisis and developing countries' policy options? Some concluding observations}

At the bottom of the global crisis of 2007-09 are systemic deficiencies in the global monetary and financial order. In particular, advanced countries with large current account surpluses, such as Germany and Japan, are not held to account for perpetually freeloading on external demand for their growth. Moreover, financial instabilities created since global finance has been unleashed induced a widespread urge to secure policy space among emerging markets. While far more excusable, the general self-insurance rush saw the global insurer's risk exposure balloon in the form of unsustainable US internal imbalances - until the bubble burst, proving the effectiveness of self-insurance to be limited. Given the US dollar's role as key reserve currency, the US consumer had been lured in to act as global borrower and spender of last resort - an invitation far too pleasant to let pass by as long as the party went on.

The global crisis triggered a massive macro policy response around the globe and, at the start of 20IO, it seems as if the world economy may be on track for recovery, led by emerging Asia in particular. Certainly stock markets have rallied strongly and recovered about half of their earlier losses. Moreover, near-zero monetary policy rates in the United States and other advanced economies have not failed to reignite surging private capital flows toward emerging markets, giving way to significant financial easing in many of these economies since March 2009. ${ }^{18}$ To be sure, in addition to what we said above about the limited effectiveness of self-insurance in barring contagion, rock-bottom policy rates and successful rebooting of financial systems at the core have been absolutely vital for recovery in emerging markets, too.

What policy options present themselves to developing countries at this juncture and what would they suggest for the unfolding recovery in the medium term? At the peak of the

I8 Reporting that the decrease in interbank positions and in international credit to nonbanks slowed during the first quarter of 2009, Baba, Gadanecz, and McGuire (2009: 17) observe: »banks also trimmed their international credit to emerging markets, but their local lending from offices in emerging market host countries remained stable. «IMF international financial statistics (IFS) data up to the second quarter of 2009 (used above) also show some early indications of a renewed reversal in capital flows. Anecdotal evidence suggests that portfolio equity flows towards emerging markets in the later part of 2009 may have exceeded previous peaks, even as mature market funds continued to see outflows - a replay of the decoupling theme may thus be under way. 
crisis developing countries had a strong self-interest to stimulate domestic demand as their export motor stalled, with international cooperation helping to forestall a general recourse to beggar-thy-neighbor policies. Propelled by a US\$ 586 billion (or I4 percent of GDP) fiscal stimulus program and mind-boggling loan expansion, China has emerged as global leader in the recovery. Can the emerging market consumer be expected to replace the US consumer and carry the torch for global growth from here on?

Beware that this would be no less than a U-turn in general policy orientation if carried to the point where emerging markets at large returned to the pre-I999 world of running a current account deficit position. While countries followed their short-term self-interest in stimulating domestic demand as their exports plunged, it seems doubtful that the latest crisis experiences may have convinced them that the world has become a safer place in which routine emerging market financial instabilities that characterized the pre-2002 world could be easily avoided.

On the other hand, in case of a continuation or return to previous patterns featuring self-insurance (cum neo-mercantilist) strategies, renewed pressure would arise for the United States to act as global spender and borrower of last resort, with US trade and current account deficits (which shrunk to less than half of their 2006 peak value during the first half of 2009) becoming reestablished as a quasi-permanent feature of the global economy. In replacement of the 'maxed-out US consumer, US fiscal policy and public debt would need to become the new engine of growth, transforming BWII into what I dubbed elsewhere: 'Bretton Woods III (Bibow 2009b and 20IO). Bretton Woods III (BWIII) may arise by default. For lack of alternatives, a dollar crisis looks decidedly unlikely.

The need and scope for the United States to play along the BWIII script also depends on whether other advanced countries like Japan and Germany (or Euroland at large) might finally mature and pursue domestic-demand-led growth strategies. In this regard, ,dollar diplomacy «ill be the foremost instrument in keeping pressure away from the United States as key reserve currency issuer. As for developing countries, reform of the global order is the key issue. At this point though reform of the global monetary order or evolution towards some multipolar or proper international (`bancor`) currency regime seems unlikely for some time. While the establishment of a Financial Stability Board at the G-2o level represented a nice gesture at a time when global systemic financial meltdown was looming, it currently looks like serious reforms to unfettered global finance may not be forthcoming either. In principle, greater collective insurance provision (through the IMF, etc.) should tend to reduce developing countries' recourse to self-insurance (and hence pressure on the United States to act as spender of last resort, too), but IMF distrust in view of past crisis experiences may be too strong without any more fundamental IMF overhaul - with some groups of countries seeking collective insurance mechanisms at a regional level instead. All these factors influence the need and scope for the United States to continue acting as global spender of last resort and issue dollar liquidity. In a related paper that assesses the sustainability of Bretton Woods 3 I highlight the role of financial globalization and >dollar leveraging in this regard, concluding that unfettered global finance seems to have both increased the 
demand for defensive policies in the rest of the world and the extraction of rent available from meeting that demand.

The reverse is true as well. Capital account management reduces the need for self-insurance and enables countries to contain rent extraction through foreign (nondirect) investment. In fact, capital account management presents itself as an alternative to self-insurance under financial globalization, which is generally available to individual countries unless they have signed away their sovereignty in this area through bilateral or multilateral commitment (Bibow 2008 - 09, Chandrasekhar 2008, UNCTAD 2009). ${ }^{19}$ In fact, in light of the crisis of 2007 - 09, developing countries would seem to be well-advised to pursue policies of comprehensive capital account management and cautious financial liberalization at their own pace - in denial of IMF preaching of the alleged, but unproven, universal benefit of the opposite. The above comparative country study may be seen as a step towards a study of factors that tend to make countries more or less vulnerable to the vagaries of global finance, especially as some countries (China and India, for instance) have continued to employ capital account management techniques. I must leave it for future research to study the country-specific conditioning factors that led to differences in outcomes identified in Section 3 above. Studying the cross-country differences in bank regulation and supervision and degrees of capital account openness (or management) should help designing a protection shield that is not built on shaky self-insurance grounds. Even if self-insurance were actually effective, and our analysis exposed severe limitations in this regard, it must also be remembered that the strategy does not at all present any free lunch for developing countries. Especially for countries running a current account surplus position, taking out self-insurance essentially presents a bargain for yield-hungry foreign investors who do not really sponsor any growth at all - other than growth in low-yielding FX reserves that are the basis for the rent extraction involved in this peculiar asset-return swapping self-insurancer transaction (Bibow 2008 - 09).

\section{References}

Auboin, M. (2004): The trade, debt and finance nexus: At the cross-roads of micro- and macroeconomics, World Trade Organization, Discussion Paper 6, Geneva.

Auboin, M. (2009): Boosting the availability of trade finance in the current crisis: Background analysis for a substantial G20 package, in: Policy Insight, 35 (June), I - 7 .

Baba, N., Gadanecz, B., McGuire, P. (2009): Highlights of international banking and financial activity, in: BIS Quarterly Review, September, $17-25$.

Baba, N., McCauley, R.N., Ramaswamy, S. (2009): US dollar money market funds and nonUS banks, in: BIS Quarterly Review, March, 65-8I.

I9 In the fall of 2009 some countries introduced specific measures to cool hot money`, including Brazil's two percent levy on portfolio inflows and a similar move in Taiwan, see Beatti et al. (2009). 
Bank for International Settlements [BIS] (2009): $79^{\text {th }}$ Annual Report, Basle, Switzerland: Bank for International Settlements.

Beatti, A., Brown, K., Garnham, P., Wheatley, J., Jung-a, S., Lau, J. (2009): Worried nations try to cool hot money, in: FT.com, November 19, 2009.

Bergsten, F. (2008): Trade has saved America from recession, in: FT.com, July I, 2008, URL: http://blogs.ft.com/economistsforum/2008/o7/trade-has-saved-america-fromrecession/.

Berkmen, P., Gelos, G., Rennhack, R., Walsh, J.P. (2009): The global financial crisis: Explaining cross-country differences in the output impact, International Monetary Fund, Working Paper 09/280, Washington, DC.

Bernanke, B.S. (2005): The global saving glut and the US current account deficit, Federal Reserve Board, Remarks, March IO, 2005.

Bernanke, B.S. (2009): Asia and the global financial crisis, Speech, Board of Governors, October I9, 2009, URL: http://www.federalreserve.gov/newsevents/speech/bernanke2oo9iorga. htm.

Bibow, J. (2007): Global imbalances, Bretton Woods II, and Euroland's role in all this, in: Bibow, J., Terzi, A. (eds.), Euroland and the World Economy - Global Player or Global Drag?, London: Palgrave, $15-42$.

Bibow, J. (2008): The international monetary (non-)order and the sglobal capital flows paradoxı, in: Hein, E., Spahn, P., Niechoj, T., Truger, A. (eds.), Finance-led Capitalism?, Marburg: Metropolis, 219-48.

Bibow, J. (2008 - 09): Insuring against private capital flows: Is it worth the premium? What are the alternatives?, in: International Journal of Political Economy, 37(4), 5- 30.

Bibow, J. (2009a): Keynes on Monetary Policy, Finance and Uncertainty: Liquidity Preference Theory and the Global Financial Crisis, London and New York: Routledge.

Bibow, J. (2009b): Toward Bretton Woods 3? Prospects for global rebalancing, New America Foundation, Contract Policy Paper, October 7, Washington, DC, URL: http://www. newamerica.net/publications/policy/toward_bretton_woods_3.

Bibow, J. (2009c): The Euro and its guardian of stability: The fiction and reality of the tenth anniversary blast, The Levy Economics Institute of Bard College, Working Paper 583, Annandale-on-Hudson, NY.

Bibow, J. (20I0): Bretton Woods 2 is dead, long live Bretton Woods 3?, The Levy Economics Institute of Bard College, Working Paper 597, Annandale-on-Hudson, NY.

Buchanan, R. (2009): Remittances from US to Mexico drop I4\%, in: FT.com, January 4, 2009. Chandrasekhar, C.P. (2008): Global liquidity and financial flows to developing countries: New trends in emerging markets and their implications, United Nations, G-24 Discussion Paper 52, New York and Geneva.

D’Arista, J. (2007 - 08): US Debt and global imbalances, in: International Journal of Political Economy, 36(4), I2 - 35.

Dooley, M., Folkerts-Landau, D., Garber, P. (2003): An essay on the revised Bretton Woods System, NBER Working Paper 997I, Cambridge, MA. 
Dooley, M., Folkerts-Landau, D., Garber, P. (2009): Bretton Woods II still defines the international monetary system, NBER Working Paper I473I, Cambridge, MA.

Eichengreen, B., O’Rourke, K. (2009): A tale of two depressions, in: voxeu.com, April 6, 2009.

Escaith, H. (2009): Trade collapse, trade relapse and global production networks: Supply chains in the Great Recession, Munich Personal RePEc Archive, Paper 18274, Munich.

European Central Bank [ECB] (2009): EU Banks' Funding Structures and Policies, Frankfurt: European Central Bank.

Griffith-Jones, S., Ocampo, J.A. (2009): The financial crisis and its impact on developing countries, International Policy Centre for Inclusive Growth, Working Paper 53, Brasilia.

Godley, W., Papadimitriou, D.B., Hannsgen, G., Zezza, G. (2007): The US economy: Is there a way out of the woods?, The Levy Economics Institute of Bard College, Strategic Analysis, November 2007, Annandale-on-Hudson, NY.

Institute for International Finance [IIF] (2009a): Capital flows to emerging market economies, Institute for International Finance, Research Note, January 27, 2009, Washington, DC.

Institute for International Finance [IIF] (2009b): Capital flows to emerging market economies, Institute for International Finance, Research Note, October 3, 2009, Washington, DC.

International Monetary Fund [IMF] (2007): World Economic Outlook, October 2007, Washington, DC: International Monetary Fund.

International Monetary Fund [IMF] (2008): World Economic Outlook, April 2008, Washington, DC: International Monetary Fund.

International Monetary Fund [IMF] (2009a): Review of recent crisis programs, September I4, 2009, Washington, DC: International Monetary Fund, URL: http://www.imf.org/external/np/pp/eng/2009/o9I409.pdf.

International Monetary Fund [IMF] (2009b): The flexible credit line - Guidance on operational issues, November 2, 2009, Washington, DC: International Monetary Fund, URL: http://www.imf.org/external/np/pp/eng/2009/ıIO209.pdf.

Kregel, J. (2004): External financing for development and international financial instability, G-24 Discussion Paper No. 32.

Kregel, J. (2008): Financial flows and international imbalances - The role of catching up by late industrializing developing countries, in: Hein, E., Niechoj, T., Spahn, P., Truger, A. (eds.), Finance-led Capitalism? Macroeconomic Effects of Changes in the Financial Sector, Marburg: Metropolis, and also: Levy Economics Institute, Working Paper No. 528.

Ma, G., McCauley, R.N. (2007): Do China’s capital controls still bind? Implications for monetary autonomy and capital liberalization, Bank for International Settlements, Working Paper 233, Basel.

Malouche, M. (2009): Trade and trade finance developments in I4 developing countries post September 2008: A World Bank survey, The World Bank, Policy Research Working Paper 5I38, Washington, DC.

McCauley, R.N., McGuire, P. (2009): Dollar appreciation in 2008: Safe haven, carry trades, dollar shortage and overhedging, Bank for International Settlements, Quarterly Review, December 2009, Basel. 
McGuire, P., von Peter, G. (2009): The US dollar shortage in global banking and the international policy response, Bank for International Settlements, Working Paper 29I, Basel.

Mohan, R. (2009): Capital flows in India, Bank for International Settlements, Working Paper 44, Basel.

Ocampo, J.A. (2007 - 08): The instability and inequities of the global reserve system, in: International Journal of Political Economy, 36(4), 71 - 96.

Richardson, K., Zuckerman, G. (2007): Subprime game's reckoning day, in: Wall Street Journal, February 2, 2007.

Subramanian, A. (2008): Self-insurance - The debate India must have, in: Business Standard, November 26, 2008.

UNCTAD (2009): Trade and Development Report, 2009, Geneva: United Nations Conference on Trade and Development.

World Bank (2009): Global Development Finance, September, Washington, DC: The World Bank.

World Trade Organization (2009): The challenges of trade financing, URL: http://www.wto. org/english/thewto_e/coher_e/challenges_e.htm.

Wynne, M.A., Kersting, E.K. (2009): Trade, globalization and the financial crisis, in: Economic Letter, $4(8), \mathrm{I}-8$.

Zhou, X. (2009): Reform the international monetary system, People's Bank of China, URL: www.pbc.gov.ch/english.

Zuckerman, G. (2007): How street hit lender, in: Wall Street Journal, March 29, 2007. 
